\title{
[2] The Scene of Convalescence
}

\section{The Horror of Origins}

If the critics of decadent writers employ a Lombrosian rhetoric of sickness, the decadents themselves might be said to adopt a Baudelairean rhetoric of sickness in their descriptions of convalescence. Far from being terms of opprobrium, eviration and feminization of the (male) protagonist are constitutive elements of this rhetoric and of the decadent aesthetic. The critics' criticism is thus less an analysis of these texts than a repetition of the fundamental move whereby the decadents accepted their "negative" epithet and transformed it into praise. The critics, however, move in the opposite direction: they take the sickness, eviration, and feminization valorized by the decadents and transform those terms into defects and shortcomings.

The scenes of convalescence this chapter examines are four: Charles Baudelaire's Peintre de la vie moderne, J. K. Huysmans's $A$ rebours, D'Annunzio's Piacere, and Friedrich Nietzsche's preface to the second edition of The Gay Science. The three names surrounding that of D'Annunzio represent obligatory citations in any study of decadence, citations made obligatory both by his critics and by D'Annunzio himself. ${ }^{1}$ The problem posed by D'Annunzio's texts

1. Almost all the bibliography on D'Annunzio could be cited at this point; two articles covering this territory point out all the obligatory stops in a synthetic fashion: Giuseppe Petronio, "Il decadentismo: La parola e la cosa," and Norbert Jonard, "D'Annunzio romanziere decadente," both in Quaderni del Vittoriale 36 (1982): $9-48$. 
is not to uncover unacknowledged sources but to read and interpret an abundance of acknowledgments. The critic whose quest is for sources, in the traditional mode of source criticism, may well feel preempted by this abundance and find herself looking for depth when all is surface, for decadent texts flaunt their intertextuality, footnote themselves endlessly, self-consciously present their own literary genealogies. Indeed, a text such as $A$ rebours, the so-called bible of decadence, might more aptly be termed the bibliography of decadence; it proposes not its own rereading for spiritual guidance but the reading of its sources for artistic guidance. ${ }^{2}$ The predominance of metalanguage in $A$ rebours represents a general tendency; the presence of metalanguage in fictional texts and of literary language in philosophical texts is a distinguishing feature of decadent narrative. Within the boundaries of individual texts (insofar as any text can be said to have boundaries) it is that metalanguage, that tension between language and metalanguage, which seems to bring all to the shimmering surface. Digging for buried sources in these texts is like searching for the vanishing point of a Gustav Klimt painting; in order to read either the literary text or the painting, a different perspective is needed.

$A$ rebours is an extreme case, but Il piacere, too, is inlaid with intertextual references. Literary genealogies seem, in D'Annunzio's texts, to be traceable with ease, without anxiety, and critics have often followed these references as though they were the reassuring bread crumbs and pebbles strewn by Hansel and Gretel: the path to the good and true father. Thus the influences of Dostoevsky and Tolstoy can be noted in L'Innocente, of Nietzsche in Trionfo della morte, of Maupassant in Le novelle della Pescara, to name but a few. ${ }^{3}$

2. In the decadent code, literary guidance is spiritual guidance, just as spiritual guidance as well as sacred objects become literary objects. For an insightful investigation of how the language of decadent texts "metamorphoses" evangelical language, see Paolo Valesio, "Il coro degli Agrigentini," Quaderni del Vittoriale 36 (1982): 63-92.

3. Francesco Flora, in his D'Annunzio (Naples: Ricciardi, 1926), continues the list: "We have said it: in the final analysis, D'Annunzio's history would turn out to be a repetition of his sources, and the malicious would say, of his plagiarism. Queueing up we find Maupassant, Flaubert, Baudelaire, Zola, de Musset, Verlaine, Rimbaud, Péladan, Lorrain, Coppée, de Goncourt, de Banville, Gauthier, Maeterlinck, Verhaeren, de Régnier, Gide, France, Claudel: and then Tolstoy, Dostoevsky, and perhaps Korolenko; and Byron, Keats, 
These clearly marked trails (the latter, one of the infamous plagi, is paradoxically the most clearly marked of all, the path so clear that D'Annunzio does not even bother to point to it) can be likened to the path of pebbles which, glowing in the moonlight, led the siblings safely home. In D'Annunzio's novels, those trails often lead to reassuring fathers who seem not to threaten the integrity of the text. The names of writers and poets, painters and musicians decorate D'Annunzio's texts as though they were paintings hung on the walls of a villa. In fact, D'Annunzio's last residence, Il Vittoriale degli Italiani, mirrors his texts and constitutes a metalanguage for his novels and poetry. It is a house of citation in which Dante's "Tre donne intorno al cor" is inscribed upon the beams of his bedroom; a jewel-encrusted tortoise like that of Huysmans's Jean Des Esseintes still sits on the dining table, and Michelangelo's Sibyls perch like bathing beauties above his bathtub. This easy quotation becomes, according to the notorious charges of plagiarism, sleazy quotation when D'Annunzio borrows freely from Maupassant, Verlaine, or Maeterlinck without paying "due homage." D'Annunzio seems to pose as the sort of figure Harold Bloom sees in Shakespeare: a strong father who absorbs his precursors absolutely. ${ }^{4}$ For Bloom, however, D'Annunzio would come too

Shelley, Poe, Swinburne, Oscar Wilde, Kipling, Walt Whitman; and then Wagner, Nietzsche, and then Ibsen, and so forth. The list of Italian writers would be longer still, from Vettori to Megalotti to Tommaseo to Carducci, leaving aside the classics" (11). The classic accusations of plagiarism are Enrico Thovez, Il pastore, ii gregge e la zampogna (Naples: Ricciardi, 1910), and L'arco di Ulisse (Naples: Ricciardi, 1921); and Gian Pietro Lucini, Antidannunziana (Milan: Studio Editoriale Lombardo, 1914).

4. "Shakespeare is the largest instance in the language of a phenomenon that stands outside the concern of this book: the absolute absorption of the precursor." Such absorption is possible only before the romantic watershed: "With the postEnlightenment passion for Genius and the Sublime, there came anxiety too." Harold Bloom, The Anxiety of Influence: A Theory of Poetry (1973; rpt. London: Oxford University Press, 1981), 11, 27. If there is such anxiety in D'Annunzio's poetry, it is the absolute precursor in Italian poetry-Dante-who provokes it. Laus vitae, an 8,400-line poem, is an initiate's voyage through the human and pagan comedy; D'Annunzio rewrites the story of Paolo and Francesca in the play Francesca da Rimini; the very phrases used by D'Annunzio to categorize his works, "prose di romanzi" and "versi d'amore e di gloria," are taken from Purgatorio 26: "Versi d'amore e prose di romanzi / soverchiò tutti." The reference is to Dante's precursor Arnaut Daniel. For a discussion of Francesca da Rimini as 
late to occupy such a position, and the charges of plagiarism in D'Annunzio's case seem to corroborate Bloom's notion of the impossibility of such "belated" ease. In fact, the critics disturbed by D'Annunzio's nonchalance take upon themselves the romantic anxiety of influence from which D'Annunzio himself seems not to suffer. Literary "inventions" are, for D'Annunzio, not private property but possibilities of language:

Un verso perfetto è assoluto, immutabile, immortale; tiene in sé le parole con la coerenza d'un diamante; chiude il pensiero come in un cerchio preciso che nessuna forza mai riuscirà a rompere; diviene indipendente da ogni legame e da ogni dominio; non appartiene più all'artefice, ma è di tutti e di nessuno, come lo spazio, come la luce, come le cose immanenti e perpetue. Un pensiero esattamente espresso in un verso perfetto è un pensiero che già esisteva preformato nella oscura profondità della lingua.'

[A perfect line of verse is absolute, immutable, immortal; it holds words within it with the coherence of a diamond; it encloses thought as though within a precise circle which no force will ever break; it becomes independent of all ties and all domination; it no longer belongs to the artifex but to everyone and no one, like space, like light, like all things immanent and perpetual. A thought precisely expressed in a perfect verse is a thought that already existed preformed in the obscure depths of language.]

Not in the depths of an individual psyche but in the depths of language-here lies D'Annunzio's modernity. Linguistic and literary materials and options circulate like space, like light, as though freed from the ties that anchored them to the past. Thus D'Annunzio is as free to combine the Renaissance patina of his

a critical response to Dante, see Paolo Valesio, "Dante e D'Annunzio," in Quaderni Dannunziani 3-4 (1988): 191-222.

5. Gabriele D'Annunzio, Il piacere, in Prosedi romanzi, Tutte le opere di Gabriele D'Annunzio, ed. Egidio Bianchetti, 5th ed. (Milan: Mondadori, 1955), 1:150, hereafter cited in the text. 
prose with a description of an airplane as he is to transpose a Maupassant tale into his native Pescara. Easy quotation becomes, rather than a sign of exhaustion or despair, an epigone's delight.

The scene of convalescence enacts the double movement of modernity whereby the past is canceled as diachrony in order that it may become the present: "The human figures that epitomize modernity," writes Paul de Man, "are defined by experiences such as childhood or convalescence, a freshness of perception that results from a slate wiped clear, from the absence of a past that has not yet had time to tarnish the immediacy of perception (although what is thus freshly discovered prefigures the end of this very freshness), of a past that, in the case of convalescence, is so threatening that it has to be forgotten." The forgetfulness that characterizes the first moment in Baudelaire's, Nietzsche's, and D'Annunzio's portrayals of convalescence is followed by a second moment of total, and arbitrary, recall: "Comme il a été sur le point de tout oublier, il se souvient et veut avec ardeur se souvenir de tout" ["As he has been on the brink of total oblivion, he remembers, and fervently desires to remember, everything"]. 7 So Baudelaire describes the convalescent in Le peintre de la vie moderne. D'Annunzio's Andrea Sperelli exhibits the same symptoms; at first a "creatura uscita da un fresco bagno letèo, immemore e vacua" ["creature emerged from a cool Lethean bath, empty and without memory"], the convalescent poet passes to a second moment of uncontrolled remembrance:

Ma questo periodo di visioni, di astrazioni, di intuizioni, di contemplazioni pure, questa specie di misticismo buddhistico e quasi direi cosmogonico, fu brevissimo. . . . Un giorno, nell'ora meridiana, mentre la vita delle cose pareva sospesa, il

6. Paul de Man, "Literary History and Literary Modernity," in Blindness and Insight: Essays in the Rhetoric of Contemporary Criticism (New York: Oxford University Press, 1971), 157. De Man discusses Baudelaire's Peintre de la vie moderne and Nietzsche's Of the Use and Misuse of History for Life and does not attribute delight to the writer who finds himself in the predicament of modernity.

7. Charles Baudelaire, Le peintre de la vie moderne, in Oeuvres complètes, ed. Claude Pichois, Bibliothèque de la Pléiade (Paris: Gallimard, 1976), 2:690; The Painter of Modern Life and Other Essays, trans. Jonathan Mayne (New York: Phaidon, 1964), 7, hereafter cited parenthetically in the text. 
grande e terribile silenzio gli lasciò veder dentro, d'improvviso, abissi vertiginosi, bisogni inestinguibili, indistruttibili ricordi, cumuli di sofferenza e di rimpianto, tutta la sua miseria d'un tempo, tutti i vestigi del suo vizio, tutti gli avanzi delle sue passioni. (Il piacere, 138-39)

[But this period of visions, of abstractions, of intuitions, of pure contemplations, this sort of Buddhistic and I would almost say cosmogonic mysticism was extremely brief. . . . One day, at noon, while the life of things seemed suspended, the great and terrible silence suddenly let him see inside himself vertiginous abysses, inextinguishable needs, indestructible memories, accumulations of suffering and regret, all of his misery of old, all the vestiges of his vice, and all the leftovers of his passions.]

The tabula rasa of convalescence is covered with all the impressions and vestiges of the past. The conflict between the two moments would seem to defeat the aims of modernity. The new beginning, the tabula rasa of the convalescent, figures modernity's break with the past and, according to de Man, its rupture of genealogy. ${ }^{8}$ The child and the convalescent have nothing to remember. Yet D'Annunzio's convalescent is also the last descendant of a noble lineage (as are Giorgio Aurispa in Trionfo della morte, and the three virgins of Le vergini delle rocce), "l'ultimo discendente d'una razza intellettuale" ["the last descendant of an intellectual race"] (Il piacere, 36). D'Annunzio's protagonists represent the culmination of a genealogical line rather than its rupture. This predicament of the protagonist mimes that of the decadent writer; as he attempts to create a rupture he realizes that his "modernity" consists precisely in the fact that he represents - he wishes to represent- the culmination of all that has gone before him. He is (and the theological phrase is inevitable) both the beginning and the end. While in philosophical terms, this predicament is an irresolvable paradox, in the literary practice that results genealogy becomes a major

8. See de Man, "Literary History," 148. I am indebted to de Man's discussion of modernity's desire to rupture genealogy in his seminar "The Aesthetic Theories of Baudelaire and Diderot," Yale University, Spring 1983. 
preoccupation, is thematized in order that it might be exorcized. The decadent rupture is caused by declaring oneself the end of the lineage, its culmination and fulfillment.

Decadent texts, then, encourage us to contemplate descriptions of genealogies, to admire a portrait gallery of aristocratic ancestors of both text and protagonist. Baudelaire occupies a position of honor in both Huysmans's and D'Annunzio's galleries, flanked by Verlaine, Flaubert, and in D'Annunzio's case, the English romantics and Wagner. Baudelaire's texts are recycled, reread by both Huysmans and D'Annunzio: $A$ rebours has been read, at the text's own suggestion, as an enactment of the prose poem "Any where out of the world," and Baudelaire is cited lovingly as Des Esseintes's favorite author. 'D'Annunzio makes his debt explicit in L'Innocente, citing the canonical words "dovunque fuori del mondo!" ["anywhere out of the world!"], and Baudelaire's presence is even stronger in Il poema paradisiaco and Il piacere. ${ }^{10}$ Baudelaire thus seems to stand serenely as the legitimate and legitimating father of decadentism. Yet as we gaze (and we are still following the pebble path strewn by the text), this portrait begins to assume the demented and demonic shapes of Lombroso's genealogical trees, in which the horror of origins disfigures even the most illustrious lineage. ${ }^{11}$

9. "Son admiration pour cet écrivain était sans borne. . . . Et plus Des Esseintes relisait Baudelaire, plus il reconnaissait un indicible charme à cet écrivain qui, dans un temps où le vers ne servait plus qu'à peindre l'aspect extérieur des êtres et des choses, était parvenu à exprimer l'inexprimable, grâce à une langue musculeuse et charnue, qui plus que tout autre, possédait cette merveilleuse puissance de fixer, avec une étrange santé d'expressions, les états morbides les plus fuyants, les plus tremblés, des esprits epuisés et des âmes tristes." ["His admiration for this writer knew no bounds. . . . The more Des Esseintes re-read his Baudelaire, the more he appreciated the indescribable charm of this writer who, at a time when verse no longer served any purpose except to depict the external appearance of creatures and things, had succeeded in expressing the inexpressible-thanks to a solid, sinewy style which, more than any other, possessed that remarkable quality, the power to define in curiously healthy terms the most fugitive and ephemeral of the unhealthy conditions of weary spirits and melancholy souls."] J. K. Huysmans, A rebours, ed. Marc Fumaroli (1882; Paris: Gallimard, 1977), 260-62; Against Nature, trans. Robert Baldick (1959; rpt. Middlesex, Eng.: Penguin, 1979), 146-48.

10. Gabriele D'Annunzio, L'Innocente, in Prose di romanzi, 1:417.

11. Lombroso's studies are literal illustrations of pudenda origo; see L'uomo di genio in rapporto alla psichiatria, alla storia, ed all'estetica, 6th ed. (Turin: Fratelli 
Harold Bloom's serious play on influence as a sort of influenza assumes literal form, for "Baudelaire" enters into the semiosis of decadence as both the texts that bear his signature and Baudelaire himself as text. ${ }^{12}$ Baudelaire becomes a sign when his fatal illness is mythified as the most horrifying of all writers' fates. In this double portrait we find both a reassuring likeness-Baudelaire's texts as legitimate father-and a disquieting otherness-Baudelaire as text, as paralysis and aphasia.

We have, however, not yet abandoned Hansel and Gretel in the woods, nor have we led them happily home. The problem posed by the fable, in fact, is not only how to return to the father but how to kill the mother. In the fairy tale there are two paths, a first marked with pebbles visible in the moonlight and a second laid with bread crumbs. This second path is consumed and erased, and the siblings (and, I suggest, the text) end up in the clutches of the witch, the bad mother in disguise. Our analogy ends before the happy ending in which the witch is killed, and as the children discover upon their return, their displaced desire to kill the mother has hit home-the stepmother is dead as well. By reading the texts of Baudelaire, Huysmans, D'Annunzio, and Nietzsche as readings

Bocca, 1894). Lombroso includes in an appendix the genealogical tree of the Roman Caesars and that of the Spanish dynasty from 1357 to 1700 . We may take the latter tree as an example: the dynasty stems from Pedro I of Portugal, "proavo lunatico, crudele" ["lunatic, cruel ancestor"], who belongs to the category of "criminali pazzi morali" ["morally mad criminals"] and produces Isabella di Portogallo, "che fu pazza negli ultimi anni" ["who was mad in her last years"]; Maria Tudor, "pazza isterica sterile" ["sterile, hysterical madwoman"]; Carlo V, "geniale, melanconico, epilettico . . . mangiatore e bevitore con denti brutti" ["genial, melancholic, epileptic, a great eater and drinker with bad teeth"], who belongs tc the categories of "pazzi ed imbecilli" ["madmen and imbeciles"], "epilettici" ["epileptics"] and "geniali" ["the genial"]. The dynasty ends with Carlo II, "ultimo della dinastia, a 10 anni non si reggeva in piedi, melanconico, sposò una francese senza prole, una tedesca senza prole, a 35 anni perdè i capelli e i cigli, era epilettico e morì nel 1700" ["the last of the dynasty, at the age of ten he could not stand up, was melancholic, married a childless Frenchwoman, a childless German, at the age of thirty-five lost his hair and eyelashes, was epileptic and died in 1700"] (L'uomo di genio, table xviii). We are not so far from Giorgio Aurispa's description of his family.

12. "The Cartesian reductions of time and space brought upon us the further blight of the negative aspect of poetic influence, of influenza in the realm of literature, as the influx of an epidemic of anxiety." Bloom, 38. 
of one another, thus by following the fatherly path, we may perceive traces of the other, effaced path whose erasure led to a mother: a ritual expulsion of woman is followed by her return in grotesque form. That return may call into question the genealogical rhetoric that employs the language of fatherhood, for the scene of her return is also the scene of artistic and philosophic creation: convalescence. ${ }^{13}$

The scene of convalescence to which this text will repeatedly return is that of Andrea Sperelli. In the second book of Il piacere, Sperelli retreats to a locus amoenus, Schifanoia, to convalesce after a duel in which he had, we are told, received a "mortale ferita" ["mortal wound"]. The convalescent is reborn- "la convalescenza è una purificazione e un rinascimento" ["convalescence is a purification and a rebirth"] —and discovers poetry and his own poetic vocation. This rediscovered vocation would seem to replace Sperelli's vocation in book 1 as a womanizing dandy:

L'Arte! L'Arte!-Ecco l'Amante fedele, sempre giovine, immortale. . . Come le sue mani avevan potuto oziare e lascivire su i corpi delle femmine dopo aver sentito erompere dalle dita una forma sostanziale? Come, infine, i suoi sensi avean potuto indebolirsi e pervertirsi nella bassa lussuria dopo essere stati illuminati da una sensibilità che coglieva nelle apparenze le linee invisibili, percepiva l'impercettibile, indovinava i pensieri nascosti della Natura? (Il piacere, 14647)

[Art! Art!-She is the faithful Lover, forever young, immortal. . . . How could his hands have lain idle and lascivious on the bodies of females after having felt substantial form erupt from his fingers? How, finally, could his senses have weakened and perverted themselves in base lasciviousness after having been illuminated by a sensitivity that grasped invisible lines in appearances, that perceived the imperceptible, that divined the hidden thoughts of Nature?]

13. It is striking that, according to the $O E D$, the verb to convalesce did not appear in English dictionaries or in ordinary English usage until the nineteenth century. 
The lapsed aesthete returns to his true faith. Like Saint Augustine, Sperelli leaves behind him his nugae in order to devote himself to a "purer" contemplation: convalescence is a sort of secular conversion. As Kenneth Burke has noted in his reading of Augustine, the rhetoric of conversion inevitably evokes its dialectical counterpart-perversion. ${ }^{14}$ Sperelli's dallyings are thus a prerequisite to his conversion to art. Yet Sperelli's devoted gaze soon drifts from art, the faithful lover, to Maria Ferres, turris eburnea: the expelled woman returns in the sacralized guise of a mother Mary. Dedication of poems to her similarly drifts toward an abdication of poetic voice as the narrative shifts from the third person to the "I" of Maria Ferres's diary.

This brief and already interpretive summary allows us to raise several questions: What is the relation between convalescence and creation? Why is woman expelled from the scene of convalescence, and more interesting, why and how does she return? And finally, where does convalescence take place? Responses to these questions will be drawn from descriptions of convalescence in the texts of Baudelaire, Huysmans, D'Annunzio, and Nietzsche, which will be unraveled so as to construct a text of which those descriptions are fragments. Convalescence as the scene of artistic and philosophical creation is an ideologeme of decadent texts, a narrative that lies between texts.

\section{The Liquidation of the Crowd}

Convalescence itself is a space in-between, a hazy yet paradoxically crystal-clear state between sickness and health. Introduced as a third term in the rhetoric of sickness and health, convalescence becomes the vehicle for a series of in-between states. Physiologically ambiguous - not sick-unto-death yet not quite healthy eitherthe convalescent is also socially ambiguous. Typically, he is a

14. See Kenneth Burke, The Rhetoric of Religion: Studies in Logology (1961; rpt. Berkeley: University of California Press, 1970), as well as his article on Djuna Barnes, “Version, Con-, Per-, and In-: Thoughts on Djuna Barnes' Novel Nightwood," in Language as Symbolic Action (Berkeley: University of California Press, 1966), 240-53. 
member of a historically dislocated aristocracy, a marginal and waning class, which is itself a third term between bourgeoisie and proletariat. In the texts of Huysmans and D'Annunzio the aristocrat's historical dislocation is mimed by the convalescent's topographical dislocation: both Andrea Sperelli and Jean Des Esseintes flee the city, suffering from a "dégoût du réel" which is also a "dégoût du social." Yet in Baudelaire's 1863 essay, Le peintre de la vie moderne, the convalescent's domain appears to be the social world represented synecdochically by that great nineteenth-century obsession, the urban crowd. D'Annunzio, who did not shy away from the urban crowd either in his art (notably, in Il fuoco) or in his life (in particular, in his dialogues with the crowd at Fiume) excludes the crowd from his description of convalescence, a description that in all other respects employs a "Baudelairean" rhetoric. We may uncover some reasons for this exclusion by placing the Baudelairean text in dialogue with $I l$ piacere.

As we have seen, the convalescent is a figure for the poet in $\mathrm{Il}$ piacere; in Lepeintre de la vie moderne it is a painter who is convalescent: "Supposez un artiste qui serait toujours, spirituellement, à l'état du convalescent, et vous aurez la clef du caractère de M. G." (Le peintre, 690) ["Imagine an artist who was always, spiritually, in the condition of that convalescent, and you will have the key to the nature of Monsieur G." (Mayne, 7)]. M. Constantin Guys assumes many masks - artist, man of the world, child - but the couple that interests us here is "l'homme des foules - convalescent." Baudelaire has, of course, been reading Edgar Allan Poe, whose story "The Man of the Crowd" serves as a model for his description of Guys. I quote Baudelaire's account in full, since we will have occasion to return to it:

Vous souvenez-vous d'un tableau (en vérité, c'est un tableau!) écrit par la plus puissante plume de cette époque, et qui a pour titre L'Homme des foules? Derrière la vitre d'un café, un convalescent, contemplant la foule avec jouissance, se mêle par la pensée, à toutes les penseés qui s'agitent autour de lui. Revenu récemment des ombres de la mort, il aspire avec délices tous les germes et tous les effluves de la vie; comme il a été sur le point de tout oublier, il se souvient et veut avec ardeur se souvenir de tout. Finalement, il se précipite à travers 
cette foule à la recherche d'un inconnu dont la physiognomie entrevue l'a, en un clin d'oeil, fasciné. La curiosité est devenue une passion fatale, irrésistible! (Le peintre, 689-90)

[Do you remember a picture (it really is a picture!), paintedor rather written - by the most powerful pen of our age, and entitled The Man of the Crowd? In the window of a coffeehouse there sits a convalescent, pleasurably absorbed in gazing at the crowd, and mingling, through the medium of thought, in the turmoil of thought that surrounds him. But lately returned from the valley of the shadow of death, he is rapturously breathing in all the odours and essences of life; as he has been on the brink of total oblivion, he remembers, and fervently desires to remember, everything. Finally he hurls himself headlong into the midst of the throng, in pursuit of an unknown, half-glimpsed countenance that has, on an instant, bewitched him. Curiosity has become a fatal, irresistible passion! (Mayne, 7)]

In coupling convalescent and "l'homme des foules" under the umbrella term "Constantin Guys," Baudelaire has already interpreted Poe, for Poe's man of the crowd is not the convalescent who observes the crowd but the man pursued and observed by the convalescent, "the type and genius of true crime." roles so that the convalescent himself is the man of the crowd can be read as an identification of the artist with pathology. "Baudelaire," remarked Walter Benjamin in his brilliant essay on the flaneur, "wrote no detective story because, given the structure of his instincts, it was impossible for him to identify with the detective." 16 Indeed, even in his reading he obliterates the detective's role, truncating his account of Poe at the point when the convalescent merges into the crowd. He continues with a writing of the man of the crowd's relationship to the crowd which differs greatly from Poe's story.

15. Edgar Allan Poe, "The Man of the Crowd," in Great Short Works of Edgar Allan Poe, ed. G. R. Thompson (New York: Harper \& Row, 1970), 272.

16. Walter Benjamin, Charles Baudelaire: A Lyric Poet in the Era of High Capitalism, trans. Harry Zohn (London: New Left Books, 1973), 43. 
Like Andrea Sperelli, who moves to a paradisiacal garden on the margins of society, Constantin Guys occupies a liminal position within the crowd. Guys's goal and pleasure is to "voir le monde, être au centre du monde et rester caché au monde" (Le peintre, 692) ["to see the world, to be at the centre of the world, and yet to remain hidden from the world" (Mayne, 9)]. The three activitiesto see, to be at the center, and yet not to be seen-are simultaneous rather than sequential, and yet the third term arises suddenly, paradoxically, from the previous two desires, creating a third space, which absorbs them. Thus M. Guys is not an outside observer who views the crowd from a distance, nor does he participate wholly in it. Instead, he is an outside observer inside the social sphere. "L'observateur," writes Baudelaire, "est un prince qui jouit partout de son incognito" (Le peintre, 692) ["The spectator is a prince who everywhere rejoices in his incognito" (Mayne, 9)]. This third space, inside yet outside, is occupied by a sort of secret agent; yet unlike the prince evoked by Baudelaire, he is an agent with allegiances to neither term-neither the crowd through which he wanders nor the institutions that control the crowd's meanderings. ${ }^{17}$ His only confidant is his art. The convalescent assumes as many perspectives as he does masks, artfully dodging definition and aspiring to a stance that would be both inside and outside of his class and its ideology.

Yet like the secret agent's, the convalescent's position is precarious. Not healthy enough to participate in the social mechanism (in particular, to work), yet not sick enough to be institutionalized, the convalescent teeters between two modes of falling back into social organization. It is this that he shares with the dandy of the same essay and with the wine drinker and hashish eater of Les

17. The crowd, of course, was an area of special interest to nineteenthcentury writers and criminologists. Benjamin links the appearance of pocketsized volumes called physiologies to this aspect of urban life and quotes a turnof-the-century police report: “'It is almost impossible,' wrote a Parisian secret agent in 1798, 'to maintain good behaviour in a thickly populated area when an individual is, so to speak, unknown to all others and thus does not have to blush in front of anyone.' Here the masses appear as the asylum that shields an asocial person from his persecutors. Of all the menacing aspects of the masses, this one became apparent first. It is at the origin of the detective story" (Benja$\min , 40)$. 
paradis artificiels. These "hommes déclassés, dégoûtés, désoeuvrés" ["idle, disgusted, and déclassé men"] all belong to a special ward of "les malades" and are similarly on leave from the demands and restrictions laid upon the healthy citizen:

Or, nous connaissons assez la nature humaine pour savoir qu'un homme qui peut, avec une cuillerée de confiture, se procurer instantanément tous les biens du ciel et de la terre, n'en gagnera jamais la millième partie par le travail. Se figuret-on un État dont les citoyens s'enivreraient de hachisch? Quels citoyens! quels guerriers! quels législateurs!

[We understand enough of human nature to know that a man who, with a spoonful of conserve, can instantaneously procure for himself all the benefits of heaven and earth, will never earn a thousandth part of these by toil. Can one imagine a State of which all the citizens intoxicated themselves with hashish? What citizens, what warriors and legislators! $]^{18}$

The effects of hashish, it is true, are presented as ultimately pernicious and debilitating. The hashish eater's artificial convalescence edges toward a relapse not so much because hashish prevents one from becoming a good citizen but because it annihilates the will to create and to produce: "A quoi bon, en effet, travailler, labourer, écrire, fabriquer quoi que ce soit, quand on peut emporter le paradis d'un seul coup?" ["Indeed, what is the point of working, laboring, writing, making anything at all when one can obtain paradise in a single stroke?"]. ${ }^{19}$ The work that is valued is not the labor of the common man-for him even wine is reserved for Sundays and forgetfulness-but the work of artistic creation, a work of which the wine drinker is superbly capable. "Le vin" opens with the song wine sings to the working man but closes with a parable of a guitarist who, intoxicated, intoxicates his audience with his master-

18. Charles Baudelaire, "Le poème du hachisch," Les paradis artificiels, in Oeuvres complètes, 1:438; The Poem of Hashish, in The Essence of Laughter and Other Essays, Journals, and Letters, ed. Peter Quennell, trans. Norman Cameron (New York: Meridian Books, 1956), 102.

19. Baudelaire, "Du vin et du hachisch," in Les paradis artificiels, 397. 
ful playing. Both intoxicants, wine and hashish, provide the necessary stimulus, "le développement poétique excessif de l'homme" ["the excessive poetic development of man"], ${ }^{20}$ but wine does not impair the will and desire to represent. The wine drinker, hashish eater, and convalescent exchange symptomatologies: intoxication is one of the symptoms of convalescence, the intoxicated partake of the convalescent's creative urge, and all three experience thought as an invasion. Similar analogies are engendered by similar discourses; the disguised prince of Le peintre de la vie moderne becomes in "Du vin et du hachisch" the Holy Ghost. Wine creates, in a typically decadent play on its theological value, "pour ainsi dire, une troisième personne, opération mystique, où l'homme naturel et le vin, le dieu animal et le dieu végetal, jouent le rôle du Père et du Fils dans la Trinité; ils engendrent un Saint-Esprit, qui est l'homme supérieur, lequel procède également des deux" "21 ["a third person, as it were, a mystical operation in which the natural man and wine, the animal god and the vegetal god, play the role of Father and Son in the Trinity. They engender a Holy Spirit who is the superior man who derives equally from the two of them"]. Once again a third term is introduced which encompasses and surpasses the two terms upon which it depends. M. Guys's three goals could, in fact, be said to be a secularization of this triad, if to see the world is the Father's prerogative, to be at its center the Son's, and to be mysteriously hidden from the world is the Holy Ghost's privilege.

We have assumed, following and falling prey to the suggestion of the text, that the world in which the convalescent sees yet is not seen is the social world evoked by la foule, an urban crowd. Yet this crowd turns out to be not a collection of human faces and forms but a sort of crowd effect, the watery motion of "le fleuve de la vitalité" ["the river of vitality"]:

La foule est son domaine, comme l'air est celui de l'oiseau, comme l'eau celui du poisson. Sa passion et sa profession, c'est d'épouser la foule. Pour le parfait flâneur, pour l'observateur passionné, c'est une immense jouissance que d'élire domicile

20. Ibid.

21. Ibid., 387. 
dans le nombre, dans l'ondoyant, dans le mouvement, dans le fugitif et l'infini. (Le peintre, 691)

[The crowd is his element, as the air is that of birds and water of fishes. His passion and his profession are to become one flesh with the crowd. For the perfect flaneur, for the passionate spectator, it is an immense joy to set up house in the heart of the multitude, amid the ebb and flow of movement, in the midst of the fugitive and the infinite. (Mayne, 9)]

Benjamin's remark that, for Victor Hugo, "the crowd really is a spectacle of nature" would seem to apply to Baudelaire's description as well, for the convalescent takes up his abode in a watery realm of abstractions. ${ }^{22}$ Undulating, horizonless movement associates the crowd with the sea; the grammatical femininity of la foule is foregrounded, awakened by the association of water and archetypal femininity. This association is reinforced by Guys's professional passion to marry the crowd, the jouissance that follows his marriage, as well as by "la démarche des femmes onduleuses" ["the undulous gait of the women"], which appears in the subsequent paragraph when shadowy forms begin to surface from the crowd. Contact between convalescent and crowd is erotic: ${ }^{23}$

L'amateur de la vie fait du monde sa famille, comme l'amateur du beau sexe compose sa famille de toutes les beautés trouvées, trouvables et introuvables; comme l'amateur de tableaux vit dans une société enchantée de rêves peints sur toile. Ainsi l'amoureux de la vie universelle entre dans la foule comme dans un immense réservoir d'électricité. (Le peintre, 692)

[The lover of life makes the whole world his family, just like the lover of the fair sex who builds up his family from all the beautiful women that he has ever found, or that are-or are

22. Benjamin, 62.

23. Benjamin notes that Baudelaire's sonnet "A une passante" "presents the crowd not as the refuge of a criminal but as that of love which eludes the poet. One may say that it deals with the function of the crowd not in the life of the citizen but in the life of the erotic person" (45). 
not - to be found; or the lover of pictures who lives in a magical society of dreams painted on canvas. Thus the lover of universal life enters into the crowd as though it were an immense reservoir of electrical energy. (Mayne, 9)]

The convalescent's relation to a presumably human multitude is the least human of these analogies; rather than composing a family or an "enchanted society," he merges into an undifferentiated vastness. This merging is not, however, a loss of self for in the same moment he becomes a mirror of the crowd, a "kaleidoscope doué de conscience" ["kaleidoscope gifted with consciousness"] able to represent multiplicity to his own consciousness, to absorb and become the vastness observed. The convalescent's consciousness is the only consciousness present: "C'est un moi insatiable du non-moi" (Le peintre, 692) ["He is an ' $\mathrm{I}$ ' with an insatiable appetite for the non 'I"' (Mayne, 9)]. By ingesting the non-moi, the convalescent multiplies himself (just as the hashish eater becomes multiple by ingesting hashish), and the multiplication is enacted by the text itself. Names for Constantin Guys proliferate: "l'artiste," "l'homme du monde," "l'homme des foules," "l'enfant," "le convalescent," "le génie," "le dandy," "l'amoureux," "le prince," and "le peintre de la vie moderne." The undifferentiated crowd is filtered through Constantin Guys's consciousness to become a crowd of names.

Andrea Sperelli, a man of the world, lover, dandy, a count if not a prince, enters a convalescence that is also "puerizia" ["infancy"], "adolescenza" ["adolescence"], and the awakening of genius. Like Baudelaire's convalescent, he is subject to congestion and fevers; he, too, is in search of modernity. The only term to have disappeared is "l'homme des foules," for there is no mention of an urban crowd in this convalescent's domain. One might, as Mario Ricciardi does, interpret the exclusion as an evasive and ultimately reactionary move, a polemical gesture that sweeps away the progressive causes that crowds so often represented in the nineteenth century. ${ }^{24}$ To

24. Mario Ricciardi, Coscienza e struttura nella prosa di D'Annunzio (Turin: Giappichelli, 1970). Ricciardi identifies the displacement of the urban crowd to the countryside as a polemical move that aims to oppose (ahistorical) peasant masses to the (historical) appearance of the proletarian urban crowd. D'Annunzio's refusal to accept the existence of the urban proletariat would thus be motivated by a refusal to accept its political goals. The peasant masses are, 
be sure, the crowd is a politically charged topic; a literary description of it in the nineteenth century, especially after 1848 and the Paris Commune, cannot be neutral. To espouse the crowd meant to espouse a cause, much as, to give a contemporary example, a lyrical description of a nuclear reactor would be interpreted as a political move. Indeed, the convalescent's espousal of the crowd in Le peintre de la vie moderne can be read as a sign of Baudelaire's radical, utopian impulse. The undifferentiated vastness of the crowd implies a kind of equality among elements, an equality that cannot fail to evoke political equality as well. In that same essay, the political valence comes to the fore in a strikingly nonpolitical context:

Un artiste ayant le sentiment parfait de la forme, mais accoutumé à exercer surtout sa mémoire et son imagination, se trouve alors comme assailli par une émeute de details, qui tous demandent justice avec la furie d'une foule amoureuse d'égalité absolue. (Le peintre, 698-99)

[An artist with a perfect sense of form but one accustomed to relying above all on his memory and his imagination will find himself at the mercy of a riot of details all clamouring for

Ricciardi writes, "exalted as the genuine and immutable expression of the pure values of the race and of the nation. Thus D'Annunzio prepares the myth of the juxtaposition between the pure and natural peasant world and the corrupt and artificial world of the industrial city" (83). While I agree that this displacement of the urban crowd is a polemical gesture, I would add that the polemic might also be directed toward the "dati del reale" that preoccupy Ricciardi. The representation of masses of peasants rather than workers might be interpreted as a reading of Italian political reality in the late nineteenth century, a reality which did not correspond to that of the more advanced industrial societies of France and England. D'Annunzio's representations of peasants emphasize the specificity and, in relation to the French and English models, the backwardness of Italy. The myth of "the pure and natural peasant world," opposed to the corrupt industrial city, is Ricciardi's rather than D'Annunzio's. The "pure and natural" peasant world is presented by D'Annunzio (in Terra vergine, Le novelle della Pescara, Trionfo della morte) as sickness and degeneration. D'Annunzio is interested in civilization and artificiality, not in bemoaning a lost preindustrial purity. 
justice with the fury of a mob in love with absolute equality. (Mayne, 16)]

A riot of details turns into an angry crowd that demands justice and equality; a formal problem becomes a political one. This "intrusion" of the political onto the scene of the artist's activity stands as an emblem not only of the artist in general but of the nineteenth-century writer faced with the literarization of the crowd. As a counterexample to Baudelaire, we might cite Manzoni, whose I promessi sposi is marked, in Gramsci's words, by a "paternalismo padreternale." The crowd is a gauge of political temperament; in his novel Manzoni represented the urban crowd as a plague-ridden mob. In life, Manzoni was an agoraphobic; crowds brought on epileptoid seizures, one of which he took to be a sign from God that he should convert to Catholicism. The text of his life can be interpreted through his literary texts, for they are grounded in the same ideological matrix. ${ }^{25}$ D'Annunzio's case is more complex, for as we have said, the crowd appears in several guises in his novels and life. Its exclusion from Il piacere cannot be read simply as the incompatibility of the crowd with the scene of artistic creation, for the artist's relationship to the crowd is an important theme of $\mathrm{Il}$ fuoco and of his speeches at Fiume. Nor, it seems to me, can a developmental scheme be evoked, not because I agree with Croce's denial that development ever took place but because such chronological explanations, as we have learned from Nietzsche, often mask disturbing contradictions. The reasons for the crowd's exclusion begin to appear when we read D'Annunzio through Baudelaire and when we place D'Annunzio's other novels in dialogue with $\mathrm{Il}$ piacere.

It is possible to perceive the ghost of a human multitude in the description of Sperelli's convalescence, a multitude whose humanity has, however, been liquidated:

25. Manzoni's case did not go unexplored by Lombrosians. In 1898 Paolo Bellezza wrote a case study, Genio e follia di Alessandro Manzoni. To my knowledge, more recent psychoanalytic studies of Manzoni have not dealt with this nexus between his art and life. The existing studies focus on the Monaca di Monza. See Michel David's chapter on Manzoni in Letteratura e psicanalisi (Milan: Mursia, 1967), 140-44 and 317-60, and Ferruccio Ulivi's chapter "Manzoni e la psicanalisi," in Manzoni: Storia e provvidenza (Rome: Bonacci, 1974). 
Parevagli d'essere entrato in una forma più elementare. Il passato per la sua memoria aveva una sola lontananza, come per la vista il cielo stellato è un campo uguale e diffuso sebbene gli astri sien diversamente distanti. I tumulti si pacificavano, il fango scendeva all'imo, l'anima facevasi monda; ed egli rientrava nel grembo della natura madre, sentivasi da lei maternamente infondere la bontà e la forza.

Ospitato da sua cugina nella villa di Schifanoia, Andrea Sperelli si riaffacciava all'esistenza in conspetto del mare. (Il piacere, 135-36)

[It seemed to him that he had entered a more elementary form. The past had a single distance for his memory, just as for sight the starry skies are an equal and diffuse field even though the stars are at different distances. The tumults calmed, the mud sank to the bottom, his soul was cleansed. And he reentered the womb of mother nature and felt himself maternally infused by her with goodness and strength.

The guest of his cousin in the villa at Schifanoia, Andrea Sperelli returned to existence again in sight of the sea.]

Baudelaire's convalescent sat behind the window of a cafe with the crowd before him; Sperelli faces a different vastness, the sea. Within the context of a description that closely follows the Baudelairean rhetoric of convalescence, the substitution of sea for crowd is an interpretation of Baudelaire's text. The crowd does indeed become a spectacle of nature. Moreover, it seems that the feminine valence of Baudelaire's crowd has been retained, through a paronomastic play on madre/mare (the paronomasia is, of course, even stronger in the French mer/mère). D'Annunzio expels the social element by following the language used to describe the crowd's effect, thereby emptying the crowd of any potentially social quality. Only kaleidoscopic consciousness remains:

Il mare aveva sempre per lui una parola profonda, piena di rivelazioni subitanee, d'illuminazioni improvvise, di significazioni inaspettate. Gli scopriva nella segreta anima un'ulcera ancor viva sebben nascosta e glie la faceva sanguinare; ma il balsamo poi era più soave. Gli scoteva nel cuore una chimera 
dormente e glie la incitava così ch'ei ne sentisse di nuovo le unghie e il rostro; ma glie la uccideva poi e glie la seppelliva nel cuore per sempre. Gli svegliava nella memoria una ricordanza e glie l'avvivava così ch'ei sofferisse tutta l'amarezza del rimpianto verso le cose irrimediabilmente fuggite; ma gli prodigava poi la dolcezza d'un oblìo senza fine. Nulla entro quell'anima rimaneva celato, al conspetto del gran consolatore. Alla guisa che una forte corrente elettrica rende luminosi i metalli e rivela la loro essenza dal color della loro fiamma, la virtù del mare illuminava e rivelava tutte le potenze e le potenzialità di quell'anima umana. (Il piacere, 140)

[The sea had always held a profound word for him, full of sudden revelations, unexpected illuminations, unprecedented meanings. The sea revealed to him an ulcer in his secret soul, an ulcer still alive even though hidden, and made it bleed. But the balm was gentle later. The sea reawakened a sleeping chimera in his heart and incited it so that he once again felt its claws and beak. But later the sea killed it and buried it in his heart forever. The sea awoke a recollection in his memory and revived it so that he suffered all the bitterness of regret toward things irremediably gone. But later it bestowed upon him the sweetness of an endless forgetfulness. Nothing remained concealed within that soul as it faced the great consoler. Just as a strong electrical current makes metals luminous and reveals their essence by the color of their flame, so did the virtue of the sea illuminate and reveal all the powers and potentialities of that human soul.]

D'Annunzio's sea, like Baudelaire's crowd, is a reservoir of electricity that acts upon and illuminates the subject who will record these jolts as poems or sketches. This electrical current passes from Poe through Baudelaire to D'Annunzio, welding together their descriptions of convalescence. ${ }^{26}$ But Baudelaire acts as a conductor

26. In Poe's story, we read: "For some months I had been ill in health, but was now convalescent, and, with returning strength, found myself in one of those happy moods which are so precisely the converse of ennui-moods of the keenest appetency, when the film from the mental vision departs-the $\alpha \chi \lambda v s$ os $\pi \rho \iota \nu \varepsilon \pi \eta \varepsilon \nu$ - and the intellect, electrified, surpasses as greatly its everyday 
in yet another sense, for the "continuous tides of population" and the "tumultuous sea of human heads" which appear in "The Man of the Crowd" have, through Baudelaire's mediation, become simply tides and sea. ${ }^{27}$ The crowd is banished from the D'Annunzian scene of convalescence in order to place an electrified intellect at center stage. The fevers and congestion that afflict the convalescent and sharpen his consciousness turn sight into vision. The crowd is still necessary in Baudelaire's text as the object of that vision, as the locus of the non-moi. D'Annunzio goes one step further: he internalizes that pathology so that observer and observed are truly one; it is the multiplicity of the self, the non-moi within the moi, which

condition as does the vivid yet candid reason of Leibnitz, the mad and flimsy rhetoric of Gorgias" (262). The image of an electric current is suppressed in the 1894 version of Il piacere, which D'Annunzio prepared for Georges Hérelle's 1894 French translation. It is striking that almost all the passages I have cited as evidence of a genealogical connection are deleted from this edition of $\mathrm{Il}$ piacere, among them, the entire opening paragraph of book 2 , beginning "La convalescenza è una purificazione e un rinascimento" and ending "le ali alle chimere della fantasia" (135); the passage beginning "Il desiderio aveva abbandonato il suo regno" until "la causa del non mai provato godimento" (137); the sentence beginning "Alla guisa che una forte corrente elettrica" (140); the entire passage beginning "L'ideale avvelena ogni possesso imperfetto" until "Meglio morire!" (145-48). This last deletion thereby excludes Sperelli's sonnet, his exclamations concerning what I have called his conversion to "l'Arte . . . l'Amante fedele," as well as his fears that his intelligence may not have remained intact following his illness. (This passage will be discussed in relation to Baudelairean influenza in chapter 3.) Also excluded are his disquisition on aesthetics (149-51); the passage in which Giulia Moceto and her lack of "la douce barbe feminine" are discussed (244-47); and the misogynist dinner episode (254-57). The last two exclusions could be explained as moralistic ones; in fact, in a letter to Hérelle, cited by Ivanos Ciani, D'Annunzio assured his friend and translator that he had suppressed the most scandalous passages. Yet the other passages I have cited cannot be considered scandalous from the point of view of sexual mores. It is tempting to speculate that D'Annunzio may have felt his "French connections" were too evident in the excluded passages. The problem with such an interpretation is, of course, that D'Annunzio was not wont to show any anxiety whatsoever with regard to possible accusations of plagiarism. For the 1894 version of Il piacere, see Il piacere nella stesura preparata dall'autore per l'edizione francese del 1894, ed. Ivanos Ciani (Milan: Mondadori, 1976). Georgina Harding's translation of $I l$ piacere, The Child of Pleasure, is in fact a translation of the 1894 Italian version, rather than of the original Italian.

27. Poe, 262. 
is observed. While Baudelaire's convalescent is "un miroir aussi immense que cette foule" ["a mirror as immense as this crowd"], D'Annunzio's convalescent sees himself mirrored in the immensity of the sea. Andrea Sperelli's convalescence thus prepares the ground for a later D'Annunzian convalescent, Tullio Hermil, "il multanime" ["many-souled"] of L'Innocente.

But there is yet another reason for the liquidation of the crowd in this novel about erotic pleasure, a motivation that we can reconstruct only through recourse to other D'Annunzian texts. The crowd reappears in D'Annunzio's novels like a hysterical symptom moving from one part of the body politic to another. Expelled from the description of convalescence in $I l$ piacere, the urban crowd returns in Il fuoco and, more interestingly for the present discussion, in the third and last book of the Romanzi della Rosa, Trionfo della morte. In Trionfo della morte, the urban crowd returns in displaced form as an archaic mob of peasants who descend in droves upon the sanctuary at Casalbordino. Identified more frequently by the pejorative term torma than by the neutral label folla, it is metonymically linked to that other element excluded from the scene of convalescence, woman, or rather, a particular part of woman. Baudelaire's crowd and D'Annunzio's sea are, as we have noted, characterized as "feminine" elements, as comforting, even motherly, movement. The peasant mob of Trionfo della morte might also be said to have a feminine valence, though of a different sort, for it appears as a sign of the woman's illness, a synecdoche of Ippolita. The description of this horde is a congeries of human vice and deformation:

Era uno spettacolo meraviglioso e terribile, inopinato, dissimile ad ogni aggregazione già veduta di cose e di genti, composto di mescolanze così strane aspre e diverse che superava i più torbidi sogni prodotti dall'incubo. Tutte le brutture dell'ilota eterno, tutti i vizii turpi, tutti gli stupori; tutti gli spasimi e le deformazioni della carne battezzata, tutte le lacrime del pentimento, tutte le risa della crapula; la follia, la cupidigia, l'astuzia, la lussuria, la frode, l'ebetudine, la paura, la stanchezza mortale, l'indifferenza impietrita, la disperazione taciturna; i cori sacri, gli ululi degli ossessi, i berci dei funamboli, i rintocchi della campane, gli squilli delle 
trombe, i ragli, i muggiti, i nitriti; i fuochi crepitanti sotto le caldaie, i cumuli dei frutti e dei dolciumi, le mostre degli utensili, dei tessuti, delle armi, dei gioielli, dei rosarii; le danze oscene delle saltatrici, le convulsioni degli epilettici, le percosse dei rissanti, le fughe dei ladri inseguiti a traverso la calca, la suprema schiuma delle corruttele portata fuori dai vicoli immondi delle città remote e rovesciata su una moltitudine ignara e attonita; come tafani sul bestiame, nuvoli di parassiti implacabili su una massa compatta incapace di difendersi; tutte le basse tentazioni agli appetiti brutali, tutti gli inganni alla semplicità e alla stupidezza, tutte le ciurmerie e le impudicizie professate in pieno meriggio; tutte le mescolanze erano là, ribollivano, fermentavano, intorno alla Casa della Vergine. ${ }^{28}$

[It was a marvelous and terrible spectacle, unheard of, unlike any conglomeration ever seen before, whether of men or things; a spectacle composed of mixtures so strange, so harsh and incongruous, that it exceeded the most troubled dreams produced by an incubus. All the ugliness of the eternal Helot, all the foul vices, all the stupors; all the spasms and all the deformities of baptized flesh, all the tears of repentance, all the mockery of gluttony; insanity, cupidity, cunning, lewdness, fraud, stupidity, fear, mortal fatigue, stony indifference, silent despair; sacred choirs, demoniacal shrieks, acrobatic performances, the chiming of bells, the blasts of trumpets, brayings, lowings, neighings; the crackling fires beneath cauldrons, heaps of fruits and sweets, shop windows full of utensils, draperies, arms, jewels, rosaries; the obscene contortions of dancing girls, the convulsions of epileptics, the blows of brawlers, the flight of thieves pursued in the throng; the scum of the worst corruptions brought forth from the filthy alleys of distant towns and cast upon an ignorant and amazed multitude; clouds of implacable parasites, like horseflies about cattle, falling upon the compact crowd, incapable of selfdefense; every base temptation for brutal appetites, every fraud to trick the simple and the stupid, every immodesty was

28. Gabriele D’Annunzio, Trionfo della morte, in Prose di romanzi, 1:895-96. 
exhibited in broad daylight; all mixtures were there, seething and fermenting around the House of the Virgin.]

This Pandora's box of evils and ills is a magnified portion of Ippolita herself: her epilepsy and gynecological disturbances. The scene of mass hysteria to which this passage alludes is the ostensible cause of Ippolita's hysterical attack, the lower classes of the body politic seeming to irritate the "lower" functions of the female body. That hysteria threatens to awaken the "male sacro" that afflicts her, which is an obstruction of the erotic intercourse between Ippolita and Giorgio Aurispa: "Se questo male mi prendesse fra le tue braccia? No, no, io non ti vedrò più, non voglio più vederti" (Trionfo, 920) ["What if this malady were to seize me while I was in your arms? No, no, I will not see you anymore, I do not wish to see you anymore"]. Giorgio Aurispa's reading of cause and effect, however, identifies Ippolita as the cause of mass hysteria; the crowd is Ippolita's projection: "Forse io vedo il suo sogno. E il suo sogno ha forse per causa la perturbazione che incomincia nei suoi organi e che aumenterà sino all'accesso. Non è talvolta un sogno il presagio d'un morbo covato?" (Trionfo, 918) ["Perhaps I see her dream. And perhaps the cause of her dream is the disturbance that begins in her organs and will increase until it is an attack. Is not a dream sometimes the presage of a hidden malady?"]. The crowd and the woman, linked through their sickness and surrender to physiology, come to represent the (necessary) underside of Giorgio's erotic scenarios. Ippolita's dream is but the manifestation of her physiological ills, the body's nightmare of deformation and amputation; the epileptic attack she observes and fears is a demonic version of her ecstasy in love. The crowd and the woman are elements of an erotic discourse that would be alien and antagonistic to the rhetoric of convalescence in $I l$ piacere.

Leaving aside, for the moment, the question of female sickness in D'Annunzio's novels, I nonetheless propose that the crowd is tainted by that sickness. Several discourses on sexuality meet and conflict in Il piacere, but the eroticism grounded in female sickness is absent from this section of the novel. Convalescence itself retains an erotic element (art as faithful lover, Maria Ferres as turris eburnea); like Augustine's conversion, convalescence is a turning away from a particular eros, not from eros tout court. In the sections of the 
novel that sandwich book 2, scenes of locker-room vulgarity in social gatherings (for example, Mount Edgcumbe's pornographic library or the episode concerning Sperelli's ex-lover, who lacks, much to the men's amusement and horror, "la douce barbe feminine" ["the sweet feminine beard"]) alternate with the attempts of Sperelli and Elena to "trasformare in alto sentimento un basso appetito" (Il piacere, 268) ["to transform a low appetite into noble sentiment"]. The veils of art and sentiment are rent, Sperelli's eloquence is made to seem a spiel, by contact with such mundane scenes. The eroticism of female sickness with which the crowd is associated might have a similarly demystifying effect on the convalescent's project. The convalescent is the site of an intersection between psychology and physiology; lingering sickness is the ground of a new consciousness, a new interpretation of the body's relation to thought. The crowd would thus represent a physiology the protagonist seeks to avoid, which the convalescent, for his project to be successful, must reinterpret. The convalescent, whose fevers and congestion grant him an alternative vision, explores a different physiology and proposes a different interpretation of the body.

\section{Feminization}

Convalescence is a space in-between, a vector that points toward health and away from sickness, a copresence of symptoms of health and sickness. As a commingling of opposites, convalescence becomes the ground for figures of physiological ambiguity, of, one might almost say, physiological monstrosity. Yet at first it seems quite unmonstrous that the convalescent's rebirth should be figured as a return to childhood and innocence:

Or, la convalescence est comme un retour vers l'enfance. Le convalescent jouit au plus haut degré, comme l'enfant, de la faculté de s'intéresser vivement aux choses, même les plus triviales en apparence. Remontons, s'il se peut, par un effort rétrospectif de l'imagination, vers nos plus jeunes, nos plus matinales impressions, et nous reconnaîtrons qu'elles avaient une singulière parenté avec des impressions si vivement colo- 
rées, que nous reçûmes plus tard à la suite d'une maladie physique, pourvu que cette maladie ait laissé pures et intactes nos facultés spirituelles. L'enfant voit tout en nouveauté; il est toujours ivre. (Le peintre, 690)

[Now convalescence is like a return towards childhood. The convalescent, like the child, is possessed in the highest degree of the faculty of keenly interesting himself in things, be they apparently of the most trivial. Let us go back, if we can, by a retrospective effort of the imagination, towards our most youthful, our earliest, impressions, and we will recognize that they had a strange kinship with those brightly coloured impressions which we were later to receive in the aftermath of a physical illness, always provided that that illness had left our spiritual capacities pure and unharmed. The child sees everything in a state of newness; he is always drunk. (Mayne, $7-8)]$

The vivid perceptions of the child are due to extraordinary receptiveness, to the absence of any hierarchizing faculty; even the most trivial things interest him. Baudelaire's enfant, in these lines, calls to mind another ingenuous child who perceives the poetry in particulars, Giovanni Pascoli's fanciullino. But as we read on, Baudelaire's child grows away from Pascoli's innocent, for he is subject to a congestion whose nature is uncertain:

Rien ne ressemble plus à ce qu'on appelle l'inspiration, que la joie avec laquelle l'enfant absorbe la forme et la couleur. J'oserai pousser plus loin; j'affirme que l'inspiration a quelque rapport avec la congestion, et que toute pensée sublime est accompagnée d'une secousse nerveuse, plus ou moins forte, qui retentit jusque dans le cervelet. L'homme de génie a les nerfs solides; l'enfant les a faibles. (Le peintre, 690)

[Nothing more resembles what we call inspiration than the delight with which a child absorbs form and colour. I am prepared to go even further and assert that inspiration has something in common with congestion, and that every sublime thought is accompanied by a more or less violent nervous 
shock which has its repercussion in the very core of the brain. The man of genius has very sound nerves, while those of the child are weak. (Mayne, 8; trans. modified)]

Congestion and nervous shock have turned a bright-eyed innocent into a sickly neurasthenic child who receives shocks similar to those of the pathological man of the crowd's electrified intellect. But a sentence later a different source is suggested for the child's excitation and congestion:

Mais le génie n'est que l'enfance retrouvée à volonté, l'enfance douée maintenant, pour s'exprimer, d'organes virils et de l'esprit analytique qui lui permet d'ordonner la somme de matériaux involontairement amassée. (Le peintre, 690)

[But genius is nothing more than childhood recovered at willa childhood now equipped for self-expression with manhood's capacities and a power of analysis which enables it to order the mass of raw material which it has involuntarily accumulated. (Mayne, 8)]

In order to read this passage smoothly, one must accept the pressures exerted upon us by the text to identify "organes virils" with "nerfs solides." We are thus constrained to accept the definition of virility as fortitude and forbearance (as indeed Mayne's translation does by rendering "organes virils" not as virile organs but as "manhood's capacities"). But if we resist this pressure and give full rein to the play of meaning, we are confronted with an insinuation of childhood sexuality which would have shocked Pascoli. The physiological ambiguity (if not monstrosity) thus evoked-a sexually mature, fully rational child-is a figure for the convalescent's privileged interpretation of the body's relationship to thought. Is it the "esprit analytique" that interprets a questionably childish body, the "organes virils" that give it expression? A phrase from "Un mangeur d'opium" would seem to confirm this hypothesis: "Le génie n'est que l'enfance nettement formulée, douée, maintenant, pour s'exprimer, d'organes virils et puissants" ["Genius is nothing other than childhood clearly formulated, now endowed 
with virile and powerful organs with which to express himself"]. ${ }^{29}$ An entire narrative unfolds from this image of a child onto whom have been grafted virile organs "pour s'exprimer." The convalescent has undergone not only a kind of death and rebirth but a kind of eviration. The man is reduced to a child, a child who is, however, fitted with a prosthesis, an instrument of self-expression lacking in literal childhood. The intimation of castration suggests that the return to childhood is a euphemism for feminization. Indeed, an equivalence is established not between "l'homme de génie" and "l'enfant" but between two states of being, "le génie" and "l'enfance." Thus virile organs are attributed to a feminine "enfance." Linguistic gender hints at the feminization that occurs, as we shall see, in the convalescences of Sperelli, des Esseintes, and Nietzsche. The sharply marked division between sickness and convalescence introduces a division of the "feminine"; the expulsion of woman from the scene of convalescence is not the expulsion of her attributes. Indeed, woman is expelled in order that her qualities may be abstracted and reassigned to the convalescent himself. Baudelaire's chain of terms for Constantin Guys seems ironclad in masculinity, but in the subsection "Femmes et filles" of Le peintre we find what might well be a description of Andrea Sperelli's relationship to the liquidated crowd:

Ces deux êtres ne pensent pas. Est-il bien sûr même qu'ils regardent? à moins que, Narcisses de l'imbécillité, ils ne contemplent la foule comme un fleuve qui leur rend leur image. En réalité, ils existent bien plutôt pour le plaisir de l'observateur que pour leur plaisir propre. (Le peintre, 719)

[These two beings have not a single thought in their heads. Is it even certain that they can see? Unless, like Narcissuses of imbecility, they are gazing at the crowd as at a river which reflects their own image. In truth, they exist very much more for the pleasure of the observer than for their own. (Mayne, 35)]

As in Il piacere, the crowd becomes a body of water that reflects the image of the observer. The text invites a comparison with

29. Baudelaire, "Un mangeur d'opium," Les paradis artificiels, 1:498. 
Baudelaire's convalescent as well, for these two creatures are similarly positioned on the threshold, "à la porte d'un café, s'appuyant aux vitres illuminées par devant et par derrière" (Le peintre, 719) ["at a café door, leaning against the windows lit from within and without" (Mayne, 35; trans. modified)]. Their relationship to the crowd thus constitutes a countertext to Monsieur Guys's contemplation: "Derrière la vitre d'un café, un convalescent, contemplant la foule avec jouissance, se mêle par la pensée." Moreover, in this subsection devoted to describing female types "jusqu'à la foemina simplex," a male figure is introduced only in this paragraph. These "êtres" are a "fille de théâtre" and her male companion, yet the masculine plural pronouns absorb and efface the feminine presence. The masculinization of the woman is further underscored by her unwomanly activity: "Comme son joli compagnon, elle a tout l'orifice de sa petite bouche occupé par un cigare disproportionné" (Le peintre, 719) ["Like her dainty companion, she has an enormous cigar entirely filling the aperture of her tiny mouth" (Mayne, 35)]. That smoking is considered unwomanly is confirmed by Baudelaire's description of the foemina simplex: "Elles se montrent prostrées dans les attitudes désesperées d'ennui, dans des indolences d'estaminet, d'un cynisme masculin, fumant des cigarettes pour tuer le temps" (Le peintre, 721) ["They display themselves in hopeless attitudes of boredom, in bouts of tap-room apathy, almost masculine in their cynicism, killing time with cigarettes" (Mayne, 37; trans. modified)]. The commingling of masculine and feminine in contemplating the crowd could represent merely the inability of the lower-class "êtres" to achieve the upper-class convalescent's level of consciousness. Yet if we return now to our monstrous child, we discover that he is not so dissimilar from these "Narcisses de l'imbécillité":

C'est à cette curiosité profonde et joyeuse qu'il faut attribuer l'oeil fixe et animalement extatique des enfants devant le nouveau, quel qu'il soit, visage ou paysage, lumière, dorure, couleurs, étoffes chatoyantes, enchantements de la beauté embellie par la toilette. (Le peintre, 690)

[It is by this deep and joyful curiosity that we may explain the fixed and animally ecstatic gaze of a child confronted with 
something new, whatever it be, whether a face or a landscape, gilding, colours, shimmering stuffs, or the magic of physical beauty assisted by cosmetic art. (Mayne, 8)]

At this point, the rereader of Baudelaire might assume that the phrase "la beauté embellie par la toilette" is an allusion to the later subsection "L'éloge du maquillage" in which Baudelaire argues against the commonplace that "la nature embellit la beauté" ["nature beautifies beauty"]. Encouraged by the "étoffes chatoyantes," we might, then, expect the figure of a woman to appear, for it is the woman who profits from the art of cosmetics in Baudelaire's essay. But no; our virile child contemplates a version of himself:

Un de mes amis me disait un jour qu'étant fort petit, il assistait à la toilette de son père, et qu'alors il contemplait, avec une stupeur mêlée de délices, les muscles des bras, les dégradations de couleurs de la peau nuancée de rose et de jaune, et le réseau bleuâtre des veines. Le tableau de la vie extérieure le pénétrait déjà de respect et s'emparait de son cerveau. Déjà la forme l'obsédait et le possédait. (Le peintre, 690-91)

[A friend of mine once told me that when he was quite a small child, he used to be present when his father dressed in the mornings, and that it was with a mixture of amazement and delight that he used to study the muscles of his arms, the gradual transitions of pink and yellow in his skin, and the bluish network of his veins. The picture of external life was already filling him with awe and taking hold of his brain. He was already being obsessed and possessed by form. (Mayne, 8)]

Thus, a vision of male beauty where the text teased us to expect a female one, masculine pronouns referring to the woman who contemplates her image in the riverlike crowd, suggest a tension between masculinization and femininization. The child seems to contemplate a version of himself, yet that contemplation emphasizes his femininity. Not only is the father's activity marked as womanly by the text, but the language of the mind's activity is borrowed from that of sexuality. The language of the quoted 
passage is not that of the mind's penetration into things, but of its receptivity and invasion. The child, grammatical object of the object he observes ("le pénétrait," "s'emparait de son cerveau," "l'obsédait et le possédait"), is penetrated and possessed by the image of the father. As Leo Bersani has suggested in his reading of the Journaux intimes, psychic penetrability is figurally related to sexual penetrability.

Such psychic penetrability is one of Sperelli's symptoms:

A poco a poco, in quegli ozii intenti e raccolti, il suo spirito si stendeva, si svolgeva, si dispiegava, si sollevava dolcemente come l'erba premuta in su' sentieri; diveniva infine verace, ingenuo, originale, libero, aperto alla pura conoscenza, disposto alla pura contemplazione; attirava in sè le cose, le concepiva come modalità del suo proprio essere, come forme della sua propria esistenza; si sentiva infine penetrato dalla verità che proclama l'Oupanischad dei Veda: "Hae omnes creaturae in totum ego sum, et praeter me aliud ens non est." (Il piacere, 136)

[Little by little, in this silent and intent idleness, his spirit expanded, unwound, uncoiled, lifted itself gently like grass trodden underfoot on the path; it became truthful, ingenuous, original, free, open to pure knowledge, ready for pure contemplation. It drew things into itself, conceived of them as modalities of its own being, as forms of its existence. He felt himself penetrated by the truth of the Veda Upanishad: "Hae omnes creaturae in totum ego sum, et praeter me aliud ens non est."]

The first, absorbent phase of convalescence precedes, in both Baudelaire and D'Annunzio, a second phase in which all that has been so absorbed will be expressed in the form of Guys's sketches and Sperelli's poems. In Il piacere this first phase is similarly described as a return to childhood; in the very paragraph in which this topos is introduced, a father appears:

30. See Leo Bersani, Baudelaire and Freud (Berkeley: University of California Press, 1977), 12. 
Il convalescente rinveniva sensazioni obliate della puerizia, quell'impression di freschezza che dànno al sangue puerile gli aliti del vento salso, quegli inesprimibili effetti che fanno le luci, le ombre, i colori, gli odori delle acque su l'anima vergine. Il mare non soltanto era per lui una delizia degli occhi, ma era una perenne onda di pace a cui si abbeveravano i suoi pensieri, una magica fonte di giovinezza in cui il suo corpo riprendeva la salute e il suo spirito la nobiltà. Il mare aveva per lui l'attrazion misteriosa d'una patria, ed egli vi si abbandonava con un confidenza filiale, come un figliuol debole nelle braccia d'un padre onnipossente. E ne riceveva conforto; poiché nessuno mai ha confidato il suo dolore, il suo desiderio, il suo sogno al mare invano. (Il piacere, 139-40)

[The convalescent rediscovered forgotten sensations of his childhood, that impression of freshness that the salt breeze gives to young blood, those indescribable effects produced by the lights, shadows, colors and smells of the sea on the virgin soul. The sea was not only a delight to his eyes, but also a perennial wave of peace in which his thoughts drank deep, a magic fountain of youth in which his body regained health and his spirit, nobility. The sea had for him the mysterious attraction of a fatherland, and he abandoned himself to it with filial trust, like a feeble son in the arms of an omnipotent father. And he received comfort; for no one has ever confided his pain, his desire or his dream to the sea in vain.]

To be sure, the corporeality of the Baudelairean father-all muscles, veins, and shimmering skin - is absent here, the D'Annunzian father assuming divine proportions and insubstantiality. Yet the text creates a similar ambiguity of expectations; this babe in arms is held not by a mother (as the play on marelmadre might suggest) but by a father whose name is grammatically feminine. Of itself, such a detail might be insignificant were it not exploited in Italian politico-patriotic parlance by the term madrepatria, a hermaphroditic term that D'Annunzio himself employs in his later speeches at Fiume. The sea as mother-fatherland not only comforts but subjugates, for one paragraph later we find the convalescent/child 
yoked and crushed by its powers. Like the Baudelairean father, it overwhelms and possesses the observer:

In certe ore il convalescente, sotto l'assiduo dominio d'una tal virtù, sotto l'assiduo giogo di un tal fascino, provava una specie di smarrimento e quasi di sbigottimento, come se quel dominio e quel giogo fossero per la sua debolezza insostenibili. (Il piacere, 140)

[At times, under the continuous domination of such an influence, under the assiduous yoke of such fascination, the convalescent felt a sort of bewilderment and almost fear, as though both the domination and yoke were unbearable to his weakness.]

The convalescent's earlier openness to the contemplation of the sea is intensified to a feeling of total domination. The suggestion of feminization in Sperelli's convalescence remains, however, faint; in order to strengthen it we must make yet another detour. Tension between masculinization and feminization in the scene of convalescence resonates more loudly when we add Huysmans's $A$ rebours to the texts considered.

Jean Des Esseintes, too, moves to a liminal position in order to indulge in a long (and ultimately failed) convalescence. No bomme des foules, the ailing protagonist flees contact with the crowd to establish himself in a place not too near yet not too far from the city:

En songeant à la nouvelle existence qu'il voulait organiser, il éprouvait une allégresse d'autant plus vive qu'il se voyait retiré assez loin déjà, sur la berge, pour que le flot de Paris ne l'atteignit plus et assez près cependant pour que cette proximité de la capitale le confirmât dans sa solitude.

[Thinking of the new existence he was going to fashion for himself, he felt a glow of pleasure at the idea that here he would be too far out for the tidal wave of Parisian life to reach 
him, and yet near enough for the proximity of the capital to strengthen him in his solitude. $]^{31}$

In taking leave of the city he takes leave of the debauchery that contributed to his frightful state of health; an expulsion of woman from his existence coincides with his retirement into seclusion. We need not insinuate such an expulsion into the text; it is marked clamorously and glamorously by a "repas de deuil," a sort of symphony in black which commemorates the death of his virility: "Le dîner de faire-part d'une virilité momentanément morte, étaitil écrit sur les lettres d'invitations semblables à celles des enterrements" ( $A$ rebours, 95) ["On the invitations, which were similar to those sent out before more solemn obsequies, this dinner was described as a funeral banquet in memory of the host's virility, lately but only temporarily deceased" (Baldick, 27)]. His virility buried-and virility here refers explicitly to sexual potency-Des Esseintes can devote himself to aesthetic matters. We may, at this point, add to the accumulation of Baudelairean bons mots which Huysmans's text actualizes, for in the Journaux intimes Baudelaire vividly characterizes the relationship between sexual potency and the arts: "Plus l'homme cultive les arts, moins il bande" ["The more man cultivates the arts, the fewer erections he has"]. ${ }^{32}$ Des Esseintes seems, moreover, to have been destined for just such a burial not only by his funereal childhood but by his heredity: "La décadence de cette ancienne maison avait, sans nul doute, suivi regulièrement son cours; l'effémination des mâles était allée en s'accentuant; comme pour achever l'oeuvre des âges, les des Esseintes marièrent, pendant deux siècles, leurs enfants entre eux, usant leur reste de vigueur dans les unions consanguines" ( $A$ rebours, 80). ["The degeneration of this ancient house had clearly followed a regular course, with the men becoming progressively less manly; and over the last two hundred years, as if to complete the ruinous process, the Des Esseintes had taken to intermarrying among themselves, thus using up what little vigour they had left" (Baldick,

31. Huysmans, $A$ rebours, ed. Fumaroli, 88 , Against Nature, trans. Baldick, 24 , hereafter cited parenthetically in the text.

32. Baudelaire, "Mon coeur mis à nu," in Journaux intimes, in Oeuvres complètes, $1: 702$. 
17)]. The decadent topoi of a genetically exhausted nobility and the feminization of men ("L'homme s'affine, se féminise, se divinise") merge in Huysmans as they did in Lombroso, degeneration becoming degenderation. Des Esseintes's feminization is further underscored by his nocturnal habit. Though he rejects certain seductive colors from his decorator's scheme ("Il n'y avait pas à songer davantage aux saumons, aux maïs et aux roses dont les efféminations contrarieraient les pensées de l'isolement" [ $A$ rebours, 96] ["Nor was there any point in thinking of such delicate tints as salmon pink, maize, and rose; for their very effeminacy would run counter to his ideas of complete isolation" (Baldick, 29)]), his choice of the night as most appropriate to his hours of activity ("Il ne vivait guère que la nuit [ $A$ rebours, 95] ["He lived most of his life at night" (Baldick, 28)]) is a return to childhood and to his mother's preference for heavily curtained dusk: "Elle s'absorbait de nouveau dans la nuit factice dont les épais rideaux des croisées enveloppaient la chambre" ( $A$ rebours, 81-82) ["She sank back again into the artificial night which the heavy curtains drawn across the windows created in her bedroom" (Baldick, 19)]. Interestingly, the night is one of the few "real" elements accepted by this proponent of artificiality: his mother's was an artificial night; his is a natural one. Sperelli returns to a mother nature, Des Esseintes to a naturalized mother artificiality.

While Des Esseintes's eviration is the result of illness-generic syphilis coupled with a severe dégoût $d u$ réel, the réel including women and food-Sperelli's eviration is the illness. A figurative death of virility precedes and necessitates his convalescence. The "mortale ferita" ["mortal wound"] from which Sperelli langorously recovers is inflicted in a duel with Gianetto Rutolo, a minor character who functions only as Sperelli's rival for the attentions of another minor character, Donna Ippolita. The literal wound inflicted in this duel seems not to be quite as fatal as its consequences would suggest. It is a "ferita toracica, al quarto spazio intercostale destro, penetrante in cavità, con lesione superficiale del polmone" (Il piacere, 133) ["wound penetrating the thorax through the fourth intercostal space on the right side with superficial wound of the lung"]. One is tempted to observe, as T. S. Eliot did of Hamlet, that the emotion expressed ("mortale ferita") is in excess of the facts as they appear. The literal wound is, of course, not the point; the 
effect is less important than the cause, for the duel is fought not with pistols, as might be expected in a late nineteenth-century novel, but with swords. We need not have recourse to vulgar Freudian symbolism in order to suggest that swords second the phallus, for a much stronger argument is supplied by Ariostean and Tassian versions and subversions of the phallic valence of swords and dueling. ${ }^{33}$ In the code of those chivalric romances, loss of a duel is a loss of power as well as potency; the swordless warrior is effeminate (it is for this reason that Rinaldo mirrors himself in a scudo, a womanly arm). The very anachronism of a duel with swords underscores its link with the duels of romance and marks it as phallic combat. Sperelli, then, loses the duel, lays down the sword. Death of desire is the result: "Egli riposava, poiché non desiderava più. Il desiderio aveva abbandonato il suo regno" (Il piacere, 137) ["He rested, for he no longer desired. Desire had abandoned its reign"]. Croce and Salinari's allusions to the gardens of Alcina and Armida thus begin to seem pertinent, though by hypallage, for the characteristics of Sperelli the convalescent are attributed to D'Annunzio the author. Sperelli might indeed be said to be held in thrall by Donna Maria, just as Rinaldo and Ruggiero were held by Armida and Alcina. Artistic creation takes place in just such gardens, for eviration marks the entrance into convalescence as the artist's rite of passage. Salinari and Croce posit precisely the opposite: the artist's rite of passage occurs when he takes up the sword and leaves the garden. Their criticism is a counterargument rather than a reading of the text, an assertion of an opposing ideology rather than a critique of the text's ideology.

But doesn't the image of a sorceress's garden as the locus of convalescence conflict with the expulsion of woman I have described? Is not convalescence a liberation from the dandy's dalliance with women and thus in some sense an escape from the siren song? It is and it is not. The several rhetorics employed to characterize convalescence - that of conversion, that of a return to childhood, and that of feminization-intertwine in a complex and puzzling way. Sperelli's convalescence is described in the terms of Christian conversion:

33. See John C. McLucas, "Ariosto and the Androgyne: Symmetries of Sex in the Orlando Furioso" (Ph.D. diss., Yale University, 1983). 
Dopo la mortale ferita, dopo una specie di lunga e lenta agonia, Andrea Sperelli ora a poco a poco rinasceva, quasi con un altro corpo e con un altro spirito, come un uomo nuovo, come una creatura uscita da un fresco bagno letèo, immemore e vacua. (Il piacere, 135)

[After the mortal wound, after a sort of long, slow agony, Andrea Sperelli was little by little reborn, as though with an other body and with an other spirit, like a new man, like a creature who has emerged from a cool Lethean bath, empty and without memory.]

Sperelli's rebirth and entrance into an earthly paradise recalls the cleansing of Dante the pilgrim as he crosses the river Lethe, leaves Purgatory and ascends to Paradise. The old man is taken off, the new put on, and both body and soul are renewed. The convalescent's conversion marks not a scission between mind and body but the emergence of a new consciousness that can only be described in relation to this "altro corpo":

Comprende egli che la sua vita reale è quella, dirò così, non vissuta da lui; è il complesso delle sensazioni involontarie, spontanee, inconscienti, istintive; è l'attività armoniosa e misteriosa della vegetazione animale; è l'impercettibile sviluppo di tutte le metamorfosi e di tutte le rinnovellazioni. Quella vita appunto in lui compie i miracoli della convalescenza: richiude le piaghe, ripara le perdite, riallaccia le trame infrante, rammenda i tessuti lacerati, ristaura i congegni degli organi, rinfonde nelle vene la ricchezza del sangue, riannoda su gli occhi la benda dell'amore, rintreccia d'intorno al capo la corona de' sogni, riaccende nel cuore la fiamma della speranza, riapre le ali alle chimere della fantasia. (Il piacere, 135)

[He understands that his real life is the one, I will say it thus, not lived by him. It is the complex of involuntary, spontaneous, unconscious, instinctive sensations. It is the harmonious and mysterious activity of animal vegetation, the imperceptible development of all metamorphoses and all renewals. Precisely that life performs the miracles of convales- 
cence: it heals wounds, makes up for losses, reweaves the broken woof, mends lacerated tissues, restores the tissue of the organs, reinfuses the veins with rich blood, reknots the blindfold of love about the eyes, replaits the crown of dreams about the head, reignites the flame of hope within the heart, reopens the wings of the chimera of the imagination.]

"L'altro corpo" thus seems to be the wounded body, whose imperceptible sensations are perceived in the state of convalescence; the "true" life is that which makes its way through tissues, organs, and blood and mounts toward the mind's activity: dreams, hope, imagination. But could it be that this "altro corpo" is also the "corpo dell'altro," the body of the Other? The new body, which is the consequence of eviration and which desires no longer, is, I have suggested, characterized as feminine. Thus we might say that the "old woman" is expelled in order that the "new woman" might be put on, that the converted convalescent might assume a feminine guise. The mind's activity is described in terms of corporeal activity marked as feminine; the convalescent's mind is penetrated and invaded so that it might give birth to verse:

Gli pareva che le rime, uscenti a mano a mano dal suo cervello, avessero un sapor nuovo. La consonanza gli veniva spontanea, senza ch'ei la cercasse; e i pensieri gli nascevano rimati. . . . La strofe alla fine gli usciva intera e precisa. . . . tutto il sonetto viveva e respirava come un organismo indipendente, nell'unità. (Il piacere, 151-52)

[It seemed to him that the rhymes, emerging gradually from his brain, had a new taste. Consonance came to him spontaneously and with no effort on his part; thoughts were born in rhymes. . . . Finally the verse emerged from him whole and precise. . . . the entire sonnet lived and breathed like an independent creature, in unity.]

That the poet's production should be couched in the terms of human reproduction may seem far from startling, quite commonplace; such a conception relies in fact upon the notion that "a man becomes a woman when he writes." Probably the most eloquent 
statement of this ideologeme is to be found in Gaston Bachelard's Poetics of Reverie, where, with the help of Jung, he theorizes the psychology of poetic creation: "Reverie is under the sign of the anima. When the reverie is truly profound, the being who comes to dream within us is our anima." ${ }^{34}$ Bachelard swiftly links this notion of poetic reverie to that of the androgyny of the poet's mind; the encounter of animus and anima thus constitutes the ground and essence of poetry. Jung and Bachelard are, of course, not alone in proposing that great minds are androgynous. Coleridge and Virginia Woolf preceded them, and D'Annunzio, too, seems to concur. Andrea Sperelli's muse, Maria Ferres, is an androgynous figure:

Era una voce ambigua, direi quasi bisessuale, duplice, androginica; di due timbri. Il timbro maschile, basso e un poco velato, s'ammorbidiva, si chiariva, s'infemminiva talvolta con passaggi così armoniosi che l'orecchio dell' uditore n'aveva sorpresa e diletto a un tempo e perplessità. (Il piacere, 169)

[It was an ambiguous voice, I would almost say bisexual, double, androgynous; of two timbres. The masculine timbre, low and slightly veiled, would soften, grow brighter and more feminine at times with such harmonious transitions that the ear of the listener would catch in it both delight and perplexity.]

The double synonymic dittology of this passage (bisessuale/androginica, duplice/di due timbri) is iconic of the double nature of Maria's voice. As we shall see, it is not coincidental that her voice, rather than her person, is described as androgynous. It is the voice of a muse figure, after all, which would be emphasized, but it is also true that a description of her person as androgynous would evoke the androgyne's material counterpart, the hermaphrodite, which represents not a spiritual ideal but physiological monstrosity. The very mention of androgyny seems to evoke its carnival freak cousin:

34. Gaston Bachelard, The Poetics of Reverie: Childhood, Language and the Cosmos, trans. Daniel Russell (Boston: Beacon, 1969), 62, hereafter cited in the text; trans. of La poétique de la réverie (Paris: Presses Universitaires de France, 1960). 
Andrea Sperelli's published work is titled La favola d'ermafrodito [The Tale of the Hermaphrodite]. The spiritual configuration is accompanied by its corporeal transfiguration. The coupling of androgyne and hermaphrodite, appearing in the context of the convalescent's exploration of the body's relationship to thought, disturbs the pacific notion of a spiritual union of masculine and feminine.

As a seemingly unproblematic solution to the riddle of "how a man becomes a woman when he writes," androgyny is a solution riddled with problems. Frequently offered as a rebuttal to feminist criticism, the androgyne argument is truly two-faced. While denying the validity and necessity of feminist criticism, except as a sociological approach, in the name of a genderless art or philosophy, at the same moment it excludes women from the production of art and philosophy. Feminist criticism is described as talking about physiological distinctions that have no place in the realm of the abstract qualities "masculine" and "feminine." In fact the ad feminam argument usually employed degrades the opponent's argument by claiming that it speaks of "lower" matters-skirts and pants (under which euphemisms lie the genitals) - and thereby insists upon a sexual difference that exists in a court of law but not in art: "In everyday life, the words 'man' and 'woman'-dresses and pants - are sufficient designations. But in the muted life of the subconscious, in the retiring life of a solitary dreamer, peremptory designations lose their authority. The words animus and anima have been chosen to soften the sexual designations and escape the simplicity of birth certificate classifications" (Bachelard, 66). Once we have "escaped" that simplicity, however, we discover another hitch in the notion of androgyny as the poetic condition. If androgyny consists in the man of a commingling of his dominant animus with the anima of Bachelard's reverie, what then of the woman whose anima is already dominant? This problem evokes what Luce Irigaray has called "the blind spot of an ancient dream of symmetry": the theoretical model applied to the male subject begins to grind its gears when transferred to the female subject upon which it relies as otherness. ${ }^{35}$ Bachelard, not unaware of this problem, opts for a nonsymmetrical solution:

35. See Luce Irigaray, Speculum of the Other Woman, trans. Gillian C. Gill (Ithaca: Cornell University Press, 1985), trans. of Speculum de l'autre femme (Paris: Minuit, 1974). 
On the other hand, by agreeing to the reference to two psychological instances, anima and animus, in order to classify our reflections on the essential femininity of any deep reverie, we are, we believe, protecting ourselves from an objection. One could, in fact, object-by following the automatism from which so many philosophical dialectics suffer-that if the man centered on the animus dreams the reverie in anima, the woman centered on the anima should dream in animus. Doubtless, the tension of civilization is presently such that "feminism" commonly reinforces the animus of the woman... It has been repeated often enough that feminism ruins femininity. But once again, if one wishes to give reverie its fundamental character, if he wishes to take it as a state, a present state which has no need for the scaffolding of projects, it is necessary to recognize that reverie liberates any dreamer, man or woman, from the world of demands. . . . In a pure reverie which returns the dreamer to his tranquil solitude, every human being, man or woman, finds his repose in the anima of the depths, by descending, ever descending "the slope of reverie." (Bachelard, 63)

The state of reverie is thus, for man and woman alike, found in the anima. By opting for the nonsymmetrical solution, Bachelard aims to shore up his ontology of androgyny, of the anima (within the man), as the essence of poetry. In consequence, however, it becomes clear that androgyny as the poetic condition cannot exist for the woman, for where is the animus that would supply the "andro"? In poetic reverie, she is double anima. The presence of the animus in the woman destroys (Bachelard and Jung concur) the feminine in her; animus and anima are antagonistic forces, which produce animosity. ${ }^{36}$ Far from becoming a poet, the woman cannot even

36. Though "animosity" characterizes the relationship of animus to anima in both male and female subjects, the combination woman-animus produces greater enmity: 'Whereas the cloud of 'animosity' surrounding the man is composed chiefly of sentimentality and resentment, in woman it expresses itself in the form of opinionated views, interpretations, insinuations, and misconstructions, which all have the purpose (sometimes attained) of severing the relation between two human beings." C. G. Jung, "The Synygy: Anima and Animus," in Aion: Researches into the Phenomenology of the Self, trans. R. F. C. Hull, Bollingen Series 20 (Princeton: Princeton University Press, 1968), 9:2, 16. 
speak, for Bachelard describes immersion in the anima as a state that drowns the dreamer: "Reading, ever reading, the sweet passion of the anima. But when, after having read everything, one sets before himself the task of making a book out of reveries, it is the animus which is in the harness" (Bachelard, 65). The woman's animus could conceivably return at this moment, but Bachelard no longer concerns himself with the relationship of the woman to reverie. Without the androgynous mixture of masculine and feminine, one cannot, it seems, even speak. Bachelard's persistent efforts to idealize sexual difference as animus and anima, in order "not to fall victim to simplistic physiological designation" (Bachelard, 66), rely not on the harmonious resolution of sexual difference but on the elimination of the marked term, woman, which reminds us that such difference exists. ${ }^{37}$ She is, once again, silenced, emptied of her attributes so that they may be put on by the male poet. The idealizing project would take place in her absence, but "vulgar" physiology haunts its steps; androgyny must, if it is to attain philosophical purity, be cleansed of this shadowy presence.

Physiology haunts the androgyne's foot-less steps in the very language employed to express the merging of masculine and feminine; androgyny as a spiritual configuration finds expression in the language that describes the body. Sperelli's poetic production, as I have noted, is described as giving birth. Baudelaire, in "Un mangeur d'opium," utilizes the childhood of Thomas de Quincey as an occasion to promote androgyny as the ground of genius:

L'homme qui, dès le commencement, a été longtemps baigné dans la molle atmosphère de la femme, dans l'odeur de ses mains, de son sein, de ses genoux, de sa chevelure, de ses vêtements souples et flottants,

37. The notion of androgyny as just such a pacific "resolution" permeates the criticism of decadent texts. Michel Lemaire, for example, writes: "But dandyism represents an attempt to fuse into a single, superior being the principles that divide man and the world: active and passive, yang and yin, male and female, animus and anima, sadism and masochism. . . . Does this androgyne not refer to a golden age, before the fall into duality and sin, another world in which the multiplicity of things would participate in the happiness of unity?" See Michel Lemaire, Le dandysme de Baudelaire à Mallarmé (Paris: Klincksieck, 1978), 60. 


\section{Dulce balneum suavibus}

Unguentatum odoribus,

y a contracté une délicatesse d'épiderme et une distinction d'accent, une espèce d'androgynéité, sans lesquelles le génie le plus âpre et le plus viril reste, relativement à la perfection dans l'art, un être incomplet. ${ }^{38}$

[The man who, from the beginning, has long been bathed in the soft atmosphere of woman, in the odor of her hands, her breast, her knees, her hair, her supple and flowing clothes

Dulce balneum suavibus

Unguentatum odoribus,

has contracted an epidermal delicacy and a distinction of accent, a sort of androgyny without which the most severe and virile genius remains, in relation to perfection in art, an incomplete being.]

The womanly atmosphere in which genius is bathed is the fragrance of dismembered body parts-hands, breast, knees, hair-whose enumeration overpowers their "odeur." It is proximity to female physicality rather than, say, listening to women's conversation, which completes genius and constitutes androgyny. Bachelard, too, stumbles upon a body at the very beginning of his reveries on the gender of words, a body whose monstrosity is doubled by a mixture of masculine and feminine: "Sometimes the grammatical act which gives a feminine to a being glorified in the masculine is pure clumsiness. The centaur is, of course, the prestigious ideal of a horseman who knows full well that he will never be unseated. But what might the centauress be? Who can dream of the centauress?" (Bachelard, 31). Bachelard finds comfort in botany when he discovers that centaurée is the name of a flower which "cures torn flesh," but the visual image evoked by the mention of a centauress still irks him and he adds an apologetic footnote: "The word 'centauress' must be pardoned because Rimbaud could see 'the heights where seraphic centauresses evolve among the avalanches' (Les illuminations, 'Villes'). It is essential, however, to refrain from imagining them galloping across the plains" (Bachelard, 31). It is essential,

38. Baudelaire, "Un mangeur d'opium," 1:499. 
in other words, that the physical realization of the mixture of masculine and feminine not be imagined. ${ }^{39}$ The masculine centaur was not presented as a monstrous creature but as "the prestigious ideal of a horseman"; it is the addition of the feminine which brings forth monstrosity. Such an image, for Bachelard, does not belong to the realm of the poetic. But the argument for spiritual androgyny seems to evoke precisely these sorts of images, not in the reader's private reverie but in the texts themselves. The copresence of the androgyne and the hermaphrodite in book 2 of Il piacere may stand as an emblem of this phenomenon, for this book is crowded with figures of physiological monstrosity. Sperelli's prized publication, La favola d'ermafrodito includes a "Coro dei centauri, delle Sirene e delle Sfingi" ["Chorus of Centaurs, Sirens, and Sphinxes"], and verses spoken by a chimera are cited in the text. In a feverish nightmare, Sperelli interprets storm clouds as "simile ad una zuffa di centauri" ["similar to a battle of centaurs"], as "mostri azzuffati" ["battling monsters"]. Harpies appear to him on the tree of knowledge. Androgyny as a spiritual principle is haunted by the monstrosity of the hermaphrodite; the metonymic chain produced by that hermaphrodite (here, the protagonist's text) is made up of a series of monsters, the majority of which are considered female. Harpies, sphinxes, and sirens are part woman, part animal; the chimera, part lion, part goat, part dragon, is considered a shemonster. References to these monsters appear precisely in the scene of convalescence in which the male protagonist is feminized; they seem to mirror his own condition. Part woman, part animal, they are the demonic versions of the convalescent as part woman part man. If the "altro spirito" the convalescent experiences is androgynous, then the "altro corpo" might be imagined (Bachelard would shudder in horror) as the body of a woman with the head of a man.

\section{Ventriloquism}

Des Esseintes, whom we left unpacking his collections of books, paintings, and memories in his new residence, comes closest to

39. Carolyn Heilbrun, in her Toward a Recognition of Androgyny (New York: Alfred A. Knopf, 1973), xxi, voiced a similar concern: "One danger perhaps 
imagining the convalescent's "altro corpo." Among his memories are two episodes of particular interest, the first that of Miss Urania. Having jogged his memory with a purple bonbon, which contained "une goutte d'essence feminine" ["a drop of female essence"], Des Esseintes reinvisions his encounter with a muscular American acrobat. Inversion is his fantasy:

Peu à peu, en même temps qu'il l'observait, de singulières conceptions naquirent; à mesure qu'il admirait sa souplesse et sa force, il voyait un artificiel changement de sexe se produire en elle; ses singeries gracieuses, ses mièvreries de femelle s'effaçaient de plus en plus, tandis que se développaient, à leur place, les charmes agiles et puissantes d'un mâle; en un mot, après avoir tout d'abord été femme, puis, après avoir hesité, après avoir avoisiné l'androgyne, elle semblait se résoudre, se préciser, devenir complètement un homme. (A rebours, 210-11)

[Little by little, as he watched her, curious fancies took shape in his mind. The more he admired her suppleness and strength, the more he thought he saw an artificial change of sex operating in her; her mincing movements and feminine affectations became ever less obtrusive, and in their place there developed the agile, vigorous charms of a male. In short, after being a woman to begin with, then hesitating in a condition verging on the androgynous, she seemed to have made up her mind and become an integral, unmistakable man. (Baldick, 111)]

Metamorphosis is specular; while the woman becomes a man, Des Esseintes suffers a sex change: "Il en vint a éprouver, de son côté, l'impression que lui-même se féminisait" ( $A$ rebours, 211 ) ["He got to the point of imagining that he for his part was turning female" (Baldick, 111)]. This metamorphosis is not a ground for poetic pyrotechnics on Huysmans's part but seems at first to be an occasion to épater le bourgeois by a shocking perversion: a dominatrix and an

remains: that androgyny, an ideal, might be confused with hermaphroditism, an anomalous physical condition." 
effeminate man. Des Esseintes, aroused by this "échange de sexe," is crushed when his fantasy is deflated by reality: "La transmutation des idées masculines dans son corps de femme n'existait pas" ( $A$ rebours, 212) ["No transmutation of masculine ideas into her feminine person had occurred" (Baldick, 112)]. Miss Urania turns out to be just another ordinary woman.

But Miss Urania is not just another ordinary woman; this dominatrix bears the name of one of the muses, and the "échange de sexe" is Des Esseintes-the critic's first attempt at poetic creation. The inversion of sexual roles is also an inversion of poetic roles; if the female muse's traditional role is to inspire the male poet, here it is the male aesthete who would inspire the muse, breathe masculine thoughts into her. His failure to do so generates the subsequent episode in which success is grotesquely attained.

Images of other mistresses follow that of Miss Urania, but Des Esseintes pauses at the memory of a nameless woman "dont la monstruosité l'avait tant satisfait pendant des mois" ( $A$ rebours, 213) ["whose monstrous speciality had given him months of wonderful satisfaction" (Baldick, 113)]. She is a sideshow ventriloquist, whose monstrous talent Des Esseintes is quick to exploit. Intrigued by the erotic potential of such a gift, Des Esseintes has her memorize a script that triples her monstrosity: the dialogue between the Chimera and the Sphinx from Flaubert's Tentation de Saint Antoine. Marble and terracotta statuettes representing the beasts are placed in the bedchamber for the occasion; then, while the ventriloquist projects the carefully rehearsed dialogue into the stone figures, Des Esseintes makes love to her. Through this ploy, Des Esseintes does indeed succeed in "transmuting masculine thoughts into a female body," for while the voice, the material support, is that of the unnamed woman, the words are those of Flaubert. The result of this transmutation is quite literally monstrous, for speech thus seems to originate in the hybrid creatures. His attempt to invert poetic roles had been a dismal failure with Miss Urania; now he succeeds vicariously by substituting a stronger poetic voice for his own. Rather than inspiring his own thoughts into the woman, he inspires the words of a beloved author into her. Indeed, in a further doubling Flaubert too appears to be a ventriloquist; just as the woman projects her voice into and through the statuettes, so Flaubert projects his poetic voice into and through the woman's body. 
For Des Esseintes, this coupling of Flaubert and the woman's body is a source of erotic titillation, but for the reader it is suggestive in another sense: ventriloquism, etymologically speech of the stomach or body, may describe the feminized convalescent's relationship to his "altro corpo" and thus may offer another solution to the riddle of how a man becomes a woman when he writes. As Baudelaire and D'Annunzio's choice of androgyny as the poetic state suggests, the convalescent's feminization is not total but a mixture of masculine and feminine. Total feminization would plunge the convalescent into silence or, as we shall see in Chapter 3 , lead him to even more brutal forms of death. What is monstrous about this particular mixture is that its constituent parts are still identifiable: the convalescent does not relinquish his voice. Indeed, projected into and through "his" evirated/feminized body-the woman's body-it becomes a poetic voice. The relationship between the body and thought which the convalescent proposes is thus figured as a male voice whose "idées masculines" issue from and by means of the woman's body.

The connection between aesthetic discourse and the woman's body is, of course, dauntingly broad and by no means limited to decadent texts. The scene of ventriloquism in $A$ rebours brings to mind a ventriloquist performance of the Enlightenment, Diderot's Bijoux indiscrets. There the ventre of ventriloquism is taken quite literally, for the speakers of that text are the vaginas of the harem. Though urged to speak of their erotic adventures, the vaginas are also well versed in aesthetics and hold forth at length upon literary and theatrical matters. Diderot himself might be said to be the ventriloquist in this case, projecting his narrative voice into and through the vaginas, for the woman's body here serves as material support for Diderot's discourse on aesthetics. But what is specific to decadent texts - and in particular, to the scene of convalescence-is that the speaker himself is dressed in a feminized body. Woman is expelled from the scene of convalescence precisely in order that the convalescent might occupy her body, might speak from her body.

Des Esseintes the convalescent-aesthete does not in fact speak through the woman's body. He is not a ventriloquist because he is not an artist, and ventriloquism provides him with little more than a means to excite his failing organs. But just as Huysmans has supplied bibliography for the decadents, so does his text offer us a 
metalanguage with which to analyze the convalescent narratives of decadent texts. The discourses of Constantin Guys, of Andrea Sperelli, and of Nietzsche in his preface to The Gay Science all pass through the woman's body. All three are ventriloquists, though the forms and results of their ventriloquism differ. For Constantin Guys, occupation of the woman's body allows a displacement of virility to a prosthetic "organe viril," which, however, expresses itself through the mundus muliebris. For Sperelli, the failed poet, occupation of the woman's body for initially poetic ends leads to ventriloquism as a form of seduction. For Nietzsche, the convalescent occupies the woman's body in order to avoid seduction, both sexual and epistemological, and thereby to arrive at a new philosophy whose mode of expression is ventriloquistic.

Michel Butor's reading of Baudelaire's life, in Histoire Extraordinaire: Essay on a Dream of Baudelaire's, suggests that Baudelaire himself might be included among the ventriloquists. While a thorough study of the text of Baudelaire's life lies beyond the scope of this book, it is striking how closely Butor's description of Baudelaire follows Baudelaire's description of Guys. Baudelaire's illness, well documented by himself and others, provides the background for a convalescent narrative written into the text of his life. ${ }^{40}$ The illness renders Baudelaire a lifelong convalescent; the assignment of a financial guardian renders him a child. Butor reads this latter loss of responsibility as a loss of manhood: "The imposition of the legal guardianship in 1844 castrated [dévirilisé]

40. Baudelaire's notes on his physical condition are included in the Journaux intimes and the Fusées. His illness, like Nietzsche's, has been mythified by members of both the literary and medical professions. The decadents themselves take up this theme. See, for example, Maurice Barrès, "La folie de Charles Baudelaire," L'oeuvre de Maurice Barrès, ed. Philippe Barrès, with a preface by François Mauriac (Paris: Au Club de l'Honnête Homme, 1965), 1:390-401, 432-42. This essay was first published in Taches d'Encre (5 November-5 December 1884). Baudelaire is one of Lombroso's favorite degenerates; see Genio e follia (Turin: Fratelli Bocca, 1882), as well as L'uomo di genio and Genio e degenerazione (Palermo: Remo Sandron, 1897). Claude Pichois, in Baudelaire: Etudes et témoignages (Neûfchatel: Baconnière, 1967), continues the medicoliterary discussion, citing both Baudelaire's correspondence and five doctoral theses in medicine written in the 1920s on Baudelaire's illness. A more recent and more extensive discussion of Baudelaire's syphilis can be found in Roger L. Williams, The Horror of Life (Chicago: University of Chicago Press, 1980). 
Baudelaire not physically but morally. His organs are intact, of course, but they are only a sign, and henceforth a deceptive one. $\mathrm{He}$ is no longer a man, he is only a child or a woman [il n'est qu'un enfant ou une femme]." This eviration and feminization, according to Butor, influence both his personal relationships and poetic activity so radically that Baudelaire himself assumes the guise of a woman in both spheres: "This does not prevent him from desiring women, from sleeping with them, or at least with one of them, but when he does so he is a woman who desires a woman. Under his man's suit, he is a Lesbian. In La Fanfarlo, his alter ego, Samuel Cramer, has published a volume of verse, Les Orfraies (The Ospreys), under the female pseudonym of Manuela de Monteverde." "F1 For Butor, however, this feminization is but a sort of flirtation with transvestitism and merely ("il n'est qu'une femme") prepares the stage for a final coup de théâtre:

Achilles never declares himself more strongly as a virile hero than among the women's clothes he was wearing on Scyros, among the daughters of Lycomedon.

The mundus muliebris is thus the necessary theatre of the appearance of genius. The more voluminous the female garments, the more decisive the victory of the poet who tears them to shreds.

Hence we understand why the Lesbian becomes the very symbol of the apprentice poet, of the man who has not yet published. Publication will reveal this superior man hidden under a woman's dress and role [sous une robe et rôle de femme]. ${ }^{42}$

This superman in the guise of a woman apparently needs his robe and rôle de femme only to gestate his ideas; the final and important poetic performance is the triumphant return of virility. ${ }^{43}$ Here

41. Michel Butor, Histoire Extraordinaire: Essay on a Dream of Baudelaire's, trans. Richard Howard (London: Jonathan Cape, 1969), 50; trans. of Histoire extraordinaire: Essai sur un rêve de Baudelaire (Paris: Gallimard, 1961).

42. Ibid., 55-56.

43. The effeminate Clark Kent is a paler version of this Achilles who rips off his womanly garments to reveal the superman underneath. 
Butor's reading of Baudelaire seems to be a repetition of the narrative of Le peintre de la vie moderne, for in the final paragraph of the section "L'artiste, homme du monde, homme des foules, et enfant," Guys's rapid sketching is portrayed as a frenetic duel, a series of feints and lunges:

Maintenant, à l'heure où les autres dorment, celui-ci est penché sur sa table, dardant sur une feuille de papier le même regard qu'il attachait tout à l'heure sur les choses, s'escrimant avec son crayon, sa plume, son pinceau, faisant jaillir l'eau du verre au plafond, essuyant sa plume sur sa chemise, pressé, violent, actif, comme s'il craignait que les images ne lui échappent, querelleur quoique seul, et se bousculant luimême. (Le peintre, 693)

[So now, at a time when others are asleep, Monsieur G. is bending over his table, darting on to a sheet of paper the same glance that a moment ago he was directing towards external things, skirmishing with his pencil, his pen, his brush, splashing his glass of water up to the ceiling, wiping his pen on his shirt, in a ferment of violent activity, as though afraid that the image might escape him, cantankerous though alone, elbowing himself on. (Mayne, 12)]

The virile organ is put to the test and the convalescent seems no longer to need his rôle de femme. The virility Guys regains is not, however, that to which Andrea Sperelli will return, for Guys's virile organ is a prosthetic one. Butor's suggestion that femininity and supervirility are linked in a superhero fashion is intriguing, but it is not at all clear that prosthetic virility excludes a rôle de femme. On the contrary, it would seem that the convalescent's feminization needs to be preserved in order that his organe viril not be a literal one. Guys's occupation of the woman's body, if not Baudelaire's, must remain aesthetic, for it is, in a professional sense, his occupation. His goals are achieved principally through his immersion in the feminine, in the mundus muliebris.

In the texts of both Nietzsche and Baudelaire, a definition of woman as all surface and no interiority facilitates the convalescent's 
occupation of her. In a breathtaking sentence, Baudelaire describes "la femme":

L'être qui est, pour la plupart des hommes, la source des plus vives, et même, disons-le à la honte des voluptés philosophiques, des plus durables jouissances; l'être vers qui ou au profit de qui tendent tous leurs efforts; cet être terrible et incommunicable comme Dieu (avec cette différence que l'infini ne se communique pas parce qu'il aveuglerait et écraserait le fini, tandis que l'être dont nous parlons n'est peut-être incompréhensible que parce qu'il n'a rien à communiquer); cet être en qui Joseph de Maistre voyait un bel animal dont les grâces égayaient et rendaient plus facile le jeu sérieux de la politique; pour qui et par qui se font et défont les fortunes; pour qui, mais surtout par qui les artistes et les poètes composent leurs plus délicats bijoux; de qui dérivent les plaisirs les plus énervants et les douleurs les plus fécondantes, la femme, en un mot, n'est pas seulement pour l'artiste en général, et pour M. G. en particulier, la femelle de l'homme. (Le peintre, 713)

[The being who, for the majority of men, is the source of the liveliest and even-be it said to the shame of philosophic pleasures - of the most lasting delights; the being towards whom, or on behalf of whom, all their efforts are directed; that being as terrible and incommunicable as the Deity (with the difference that the Infinite does not communicate because it would thereby blind and overwhelm the finite, whereas the creature of whom we are speaking is perhaps only incomprehensible because it has nothing to communicate); that being in whom Joseph de Maistre saw a graceful animal whose beauty enlivened and made easier the serious game of politics; for whom, and through whom, fortunes are made and unmade; for whom, but above all through whom, artists and poets create their most exquisite jewels; the source of the most exhausting pleasures and the most productive pains - Woman, in a word, for the artist in general and Monsieur G. in particular, is far more than just the female of man. (Mayne, 29-30)]

Baudelaire's emphases on un bel animal and par qui underline the process I have been describing. Though the expulsion of woman in 
Le peintre is less dramatic than that in $I l$ piacere, it takes place nonetheless as a denial of her existence as a subject or as an agent in the world of art. The contrast between the two uses of par qui is striking: fortunes may be made and unmade by the woman as an agent, but works of art are composed by the artist who expresses himself through, by means of, the woman. A denial of consciousness (un bel animal) is necessary in order that the woman may become a vehicle, a body emptied of spiritual content. A creature who "perhaps" has nothing to communicate becomes the artist's principal means of communication by lending her attributes to one who, presumably, can render them conscious. His poetic voice, his visual message is transmitted through this body.

In the case of Constantin Guys, immersion in the mundus muliebris is crucial for the attainment of his goal, the representation of modernity: "Il s'agit, pour lui, de dégager de la mode ce qu'elle peut contenir de poétique dans l'historique, de tirer l'éternel du transitoire" (Le peintre, 694) ["He makes it his business to extract from fashion whatever element it may contain of poetry within history, to distil the eternal from the transitory" (Mayne, 12)]. As a concretization of "le transitoire, le fugitif," fashion plays an important role in Guys's project. Indeed, the absence of the transitory element is figured as an absence of clothing, as a naked woman: "En le supprimant, vous tombez forcément dans le vide d'une beauté abstraite et indéfinissable, comme celle de l'unique femme avant le premier péché" (Le peintre, 695) ["By neglecting it, you cannot fail to tumble into the abyss of an abstract and indeterminate beauty, like that of the first woman before the fall of man" (Mayne, 13)]. The bel animal is, then, more precisely a clotheshorse, for what better object of "modern" contemplation can there be than a being inseparable from her ever-changing costume?

Quel poète oserait, dans la peinture du plaisir causé par l'apparition d'une beauté, séparer la femme de son costume? Quel est l'homme qui, dans la rue, au théâtre, au bois, n'a pas joui, de la manière la plus désintéressée, d'une toilette savamment composée, et n'en a pas emporté une image inséparable de la beauté de celle à qui elle appartenait, faisant ainsi des deux, de la femme et de la robe, une totalité indivisible? (Le peintre, 714) 
[What poet, in sitting down to paint the pleasure caused by the sight of a beautiful woman, would venture to separate her from her costume? Where is the man who, in the street, at the theatre, or in the park, has not in the most disinterested of ways enjoyed a skilfully composed toilette, and has not taken away with him a picture of it which is inseparable from the beauty of her to whom it belonged, making thus of the two things - the woman and her dress - an indivisible unity? (Mayne, 31)]

A robe and rôle de femme are thus as inseparable from each other as they are inseparable from Guys's project. Rather than, as Butor had described, dramatically ripping off his vetements de femme, Guys the painter (if not Baudelaire the poet) is intent upon adding to his wardrobe:

Tout ce qui orne la femme, tout ce qui sert à illustrer sa beauté, fait partie d'elle-même; et les artistes qui se sont particulièrement appliqués à l'étude de cet être énigmatique raffolent autant de tout le mundus muliebris que de la femme elle-même. (Le peintre, 714)

Ainsi M. G. s'étant imposé la tâche de chercher et d'expliquer la beauté dans la modernité, répresente volontiers des femmes très parées et embellies par toutes les pompes artificielles. (Le peintre, 718)

[Everything that adorns woman, everything that serves to show off her beauty, is part of herself; and those artists who have made a particular study of this enigmatic being dote no less on all the details of the mundus muliebris than on Woman herself. (Mayne, 30)]

[Having taken upon himself the task of seeking out and expounding the beauty in modernity, Monsieur G. is thus particularly given to portraying women who are elaborately dressed and embellished by all the rites of artifice. (Mayne, 34)] 
In these passages the body of the woman seems merely a support for her fashionable finery; it adds an undulating movement that better displays the sheen of satin. But her body is not only a mannequin for the display of "le transitoire, le fugitif, le contingent, la moitié de l'art" (Lepeintre, 695) ["the ephemeral, the fugitive, the contingent, the half of art" (Mayne, 13)]; it also, paradoxically, figures "l'autre moitié . . . l'éternel et l'immuable" ["the other half . . . the eternal and the immutable" $]$ necessary, according to Baudelaire, to art. The terms of Baudelaire's argument are overturned by this body, for the corps should presumably correspond to the contingent element in art, and the âme to the enduring form that the artist distills from that corps. Yet art that ignores the contingent element is figured as the body of a woman "avant le premier péché," and in attempting to describe "La modernité" (section 4), Baudelaire gives the example of the oldest profession in the world:

En pareille matière, il serait facile et même légitime de raisoner a priori. La corrélation perpétuelle de qu'on appelle l'âme avec ce qu'on appelle le corps explique très bien comment tout ce qui est matériel ou effluve du spirituel représente et représentera toujours le spirituel d'où il dérive. Si un peintre patient et minutieux, mais d'une imagination médiocre, ayant à peindre une courtisane du temps présent, s'inspire (c'est le mot consacré) d'une courtisane de Titien ou de Raphaël, il est infiniment probable qu'il fera une oeuvre fausse, ambiguë et obscure. L'étude d'un chef-d'oeuvre de ce temps et de ce genre ne lui enseignera ni l'attitude, ni le regard, ni la grimace, ni l'aspect vital d'une de ces créatures que le dictionnaire de la mode a successivement classées sous les titres grossiers ou badins d'impures, de filles entretenues, de lorettes et de biches. (Le peintre, 696)

[In a matter of this kind it would be easy, and indeed legitimate, to argue a priori. The perpetual correlation between what is called the "soul" and what is called the "body" explains quite clearly how everything that is "material," or in other words an emanation of the "spiritual," mirrors, and will always mirror, the spiritual reality from which it derives. If a painstaking, scrupulous, but feebly imaginative artist has to paint a courtesan of today by Titian or Raphael, it is only too likely that he 
will produce a work that is false, ambiguous and obscure. From the study of a masterpiece of that time and type he will learn nothing of the bearing, the glance, the smile or the living "style" of one of those creatures whom the dictionary of fashion has successively classified under the coarse or playful titles of "doxies," "kept women," lorettes, or biches. (Mayne, 14)]

The example cited threatens to undermine the Platonic terms of Baudelaire's argument; by observing the transitory element, le corps, we may arrive at the eternal element, l'âme, yet what is eternal about the most recent practitioners of the oldest profession in the world is precisely a function of the body. As though perceiving this menace, Baudelaire hastens to add that courtesans are by no means a privileged object ("Le lecteur comprend d'avance que je pourrais vérifier facilement mes assertions sur de nombreux objets autres que la femme" ["I need hardly tell you that I could easily support my assertions with reference to many objects other than women"); yet the two examples that follow receive no further attention in Le peintre. Ships are nowhere to be found, and horses, when they do appear, are merely accessories to a larger scene. Nor do these examples possess in such a marked degree the qualities necessary to Baudelaire's argument - an "immutable" form and function dressed in the style of its age. The courtesan thus offers herself as a ready-made work of art.

But there is yet another sense in which Constantin Guys does not abandon his robe and rôle de femme and in which he appears not as a superman but as a ventriloquist. The woman of " $L$ 'éloge du maquillage" (section 11) is, like Guys, an expert in the art of painting; her canvas is her body, her goal to use artifice to improve upon nature:

Ainsi, si je suis bien compris, la peinture du visage ne doit pas être employée dans le but vulgaire, inavouable, d'imiter la belle nature et de rivaliser avec la jeunesse. . . . Qui oserait assigner à l'art la fonction stérile d'imiter la nature? (Le peintre, 717)

[Thus, if you will understand me aright, face-painting should not be used with the vulgar, unavowable object of imitating fair Nature and of entering into competition with youth. . . . 
Who would dare to assign to art the sterile function of imitating Nature? (Mayne, 34)]

An artist in her own right, the cosmetician serves as a model for Constantin Guys in two senses; her painting prescribes an aesthetic at the same time as she and her painting pose for his contemplation. But if the woman is already a work of art, has already improved upon nature, then what aesthetic governs Guys's representation of her? To which of the age-old camps-mimesis or cosmesis-does Guys belong? Does he improve upon artifice as the woman improves upon nature, or is he guided by an aesthetic of imitation which Baudelaire holds in contempt? The text provides no answer, but it would seem that Guys imitates artifice: "Les artistes qui se sont particulièrement appliqués à l'étude de cet être énigmatique raffolent autant de tout le mundus muliebris que de la femme elle-même" (Le peintre, 714) ["Those artists who have made a particular study of this enigmatic being dote no less on all the details of the mundus muliebris than on Woman herself' (Mayne, 30)]. While both Butor and Baudelaire seem to understand mundus muliebris as "the woman's world," glossing it with the French monde, the expression may also refer, as it does in the Book of Esther, to the woman's cosmetics. ${ }^{44}$ It is, then, the woman's art of painting which inspires Guys, in which he must immerse himself and through which (par qui), finally, his message is transmitted. If "la peinture du visage" is the model for his aesthetic, then Guys's paintings of "les femmes et les filles" speak through those painted faces and ornamented

44. Baudelaire explicitly glosses the French monde as mundus: "Enfin, je veux dire que le goût précoce du monde féminin, mundi muliebris, de tout cet appareil ondoyant, scintillant et parfumé, fait des génies supérieurs" ["Un mangeur d'opium"] (1:499). ["In short, I mean that the precocious taste for the feminine world, mundus muliebris, for all that undulating, glittering and perfumed paraphernalia, fashions superior genius."] The French monde does not retain the double meaning of the Latin mundus, which (like the related Greek kosmos) means both "world" and "ointments, adornments." The biblical mundus muliebris, instead refers quite specifically to ointments in the phrase "et accipiant mundum muliebrem, et caetera ad usus necessaria." Liber Esther, 2:3, Biblia sacra iuxta vulgatam clementinam (Madrid: Biblioteca de Autores Cristianos, 1977). The Douay Rheims translation renders mundus muliebris as "ornaments"; the Revised Standard Version reads, "let their ointments be given them" (Book of Esther $2: 3)$. 
bodies, through nature improved by artifice. His poetic "voice" is projected through that woman's body, which supposedly had nothing to communicate. Here, with the aid of the convalescentartist, that body begins to speak and turns out to have everything to communicate. The woman is a work of art, but a mute one: "C'est une espèce d'idole, stupide peut-être" ["She is a sort of idol, perhaps a stupid one"], a sort of dummy awaiting animation and occupation by the convalescent. The convalescent's feminization and the artist's androgyny are thus the preparation for, and legitimation of, an act of ventriloquism.

In the preface to the second edition of The Gay Science, it is Nietzsche himself who poses as convalescent. His pose is, of course, not unique to this preface; in Ecce Homo, Nietzsche presents himself as a lifelong convalescent, "Der Genesende" is one of Zarathustra's incarnations, and the opposition between health and sickness furnishes rhetorical scaffolding in almost all his works. ${ }^{45}$ I speak, therefore, of the 1886 preface as a moment in Nietzsche's writings which depends upon and recalls other moments, not as a synecdoche for the opera omnia but as the most powerful mise-en-scène of the scene of convalescence.

The convalescent of this preface is strikingly Baudelairean: the steps we have taken slowly, in analyzing and describing the convalescences of Guys and Sperelli, Nietzsche takes in leaps and bounds. The first of these-the expulsion of woman-does not, strictly speaking, occur in these few pages. But if we read the preface against the background of Nietzsche's other writings, against the background of Nietzsche's repeated venomous stabs at "abortive females" and "hysterical bluestockings," at women young and old, we can say the the expulsion of woman is a precondition of Nietzsche's discourse. ${ }^{46}$ The accompanying step,

45. One of the most interesting discussions of the rhetoric of sickness in Nietzsche is Pierre Klossowski, Nietzsche et le cercle vicieux (Paris: Mercure de France, 1969). The "Lombrosian" response to Nietzsche's rhetoric of sickness and biographical illness is analyzed by Sander Gilman in his article on Nietzsche as "pathogen": "The Nietzsche Murder Case," New Literary History 14.2 (1983): 359-72, now in Difference and Patbology (Ithaca: Cornell University Press, 1985).

46. Many have written on the function and significance of "woman" in Nietzsche's writings. See, for example, Eric Blondel, "Nietzsche: Life as Metaphor," in The New Nietzsche: Contemporary Styles of Interpretation, ed. David B. Allison (New 
the liquidation of the crowd, is a similar precondition, which is merely alluded to as the "radical retreat into solitude as a self-defense against a contempt for men," 47 from which the convalescent slowly emerges. These steps taken, the narrative moves rapidly to the feminization of the convalescent and his ventriloquizing speech.

The convalescences of Constantin Guys and of Andrea Sperelli were the scene of artistic creation; Nietzsche's convalescence is the scene and source of philosophic creation. Convalescence is the preface to the work; it is placed, mimetically, before its product: "Gratitude pours forth continually, as if the unexpected had just happened - the gratitude of a convalescent - for convalescence [Genesung] was unexpected. 'Gay Science': that signifies the Saturnalia of a spirit who has patiently resisted a terrible, long pressurepatiently, severely, coldly, without submitting but also without hope-and who is now all at once attacked by hope, the hope for health, and the intoxication of convalescence" $(G S, 32)$. As in the texts of Baudelaire and D'Annunzio, convalescence is linked to intoxication as well as to rebirth and childhood: "One returns newborn . . . with merrier senses, with a second dangerous innocence in joy, more childlike" (GS, 37). And once again, the convalescent occupies a space in-between, an interstice. The Gay Science, Nietzsche tells us, contains April weather. As a month of passage between seasons, April is most appropriate to the convalescent's passage between health and sickness. Interestingly enough, April and September are described in Il piacere as "i mesi neutri" ["the neuter months"]; Sperelli's preference is for the month in which his own convalescence takes place: "Il settembre. E più feminino" (Il piacere, 178) ["September. It is more feminine"]. Nietzsche, however, changes the terms of the expected analogy, for in his text April marks not a passage from the winter behind (or sickness) to

York: Dell, 1977); Jacques Derrida, Spurs: Nietzsche's Styles/Eperons: Les styles de Nietzsche, trans. Barbara Harlow (Chicago: University of Chicago Press, 1979); Sarah Kofman, Nietzsche et la scène philosophique (Paris: Union Générale d'Editions, 1979); and Luce Irigaray, Amante marine: De Friedrich Nietzsche (Paris: Minuit, 1980).

47. Friedrich Nietzsche, The Gay Science, ed. and trans. Walter Kauf mann (1887; New York: Vintage Books, 1974), 33, hereafter cited in the text, abbreviated GS. 
the summer ahead (or health) but a moment between different sicknesses, between one winter and another: "One is instantly reminded no less of the proximity of winter than of the triumph over the winter that is coming, must come, and perhaps has already come" (GS, 32). Thus, though the convalescent experiences a "hope for health," the term summer, which might fulfill that hope and represent such a stable state, is absent. It is not health that is desirable but the perpetuation of convalescence. A stable state of health would represent precisely that which Nietzsche attacks, the immobilization of perspective and consequent scleroticization of values:

You see that I do not want to take leave ungratefully from that time of severe sickness whose profits I have not yet exhausted even today. I am very conscious of the advantages that my fickle health gives me over all robust squares [Vierschrötigen des Geistes]. A philosopher who has traversed many kinds of health and keeps traversing them, has passed through an equal number of philosophies; he simply cannot keep from transposing his states every time into the most spiritual form and distance: this art of transfiguration is philosophy. (GS, 35)

The convalescent-philosopher moves along the vector between "kinds of health"; like Nietzsche's skater, dancer, and tightrope walker, he never touches stable ground, never stops at either pole, never adopts a rigidly fixed perspective. Philosophy occupies this space in-between, the space of convalescence.

It is by traversing kinds of health that Nietzsche comes to see all previous philosophy as "a misunderstanding of the body" and, as Eric Blondel puts it, as the equivalent of a hysterical symptom, of the body's conversion into language. ${ }^{48}$ The valorization of convalescence is thus an important epistemological move. The thematization of the body and its symptoms aims to establish a new, nonhysterical relationship between the body and thought. Rather than being tyrannized by the ways in which "the sick body and its

48. "As a sickness of culture, man is born in and by bad conscience which, itself, ushers in this meta-phorical, quasi bysterical, and displaced language: it is the body's symptomatic conversion into language" (Blondel, 151). 
needs unconsciously urge, push and lure the spirit" (GS, 34), the convalescent-philosopher would lend an ear to these urgings. Yet in order to hear and give voice to these whisperings, the convalescent must, paradoxically, occupy the hysterical body par excellence: the woman's body. Giving voice is figured as giving birth: the convalescent-philosopher is an incarnation of what Nietzsche calls the "mother-type": "We philosophers are not free to divide body from soul as the people do; we are even less free to divide soul from spirit. We are not thinking frogs, nor objectifying and registering mechanisms with their innards removed: constantly we have to give birth to our thoughts out of our pain and, like mothers [mütterlich], endow them with all we have of blood, heart, fire, pleasure, passion, agony, conscience, fate and catastrophe" (GS, 35-36). That the figuration of the philosopher as mother is linked to the scene of convalescence is confirmed by passages in both The Gay Science and The Genealogy of Morals, where Nietzsche makes explicit yet another stage in the convalescent's feminization. The convalescent's otium turns out to be a lying-in, for one of the sicknesses from which he recovers is that of the bad conscience: "The bad conscience is an illness, there is no doubt about that, but an illness as pregnancy is an illness." ${ }^{49}$ True, this sort of pregnancy does not always receive a positive prognosis, but in the case of the artist and philosopher such pregnancy is the matrix of a new art and philosophy, as in these two passages from The Gay Science:

Pregnancy has made women kinder, more patient, more timid, more pleased to submit; and just so does spiritual pregnancy produce the character of the contemplative type, which is closely related to the feminine character: it consists of male mothers. (GS, 129)

Consider a continually creative person, a "mother" type in the grand sense, one who knows and hears nothing any more

49. Friedrich Nietzsche, The Genealogy of Morals, trans. Walter Kaufmann and R. J. Hollingdale (New York: Vintage Books, 1969), 88. The genealogy of Nietzsche's discourse on pregnancy can, of course, be traced to Plato's Symposium, where it is Diotima (in yet another act of ventriloquism) who expounds upon the pregnancy of the soul. 
except about the pregnancies and deliveries of his spirit. $(G S, 326)$

The philosopher's spiritual activity is described in terms of and inscribed in the body of the woman, the very body that is an object of vituperation and horror in Nietzsche's writings. Once again, woman is expelled so that her attributes might be parcelled out; her mothering function is appropriated by the philosopher as a figure for an altered relationship between the body and thought. "Woman" is a particularly seductive ground for this metaphorical operation: vituperation of women frequently relies upon a rhetorical move whereby manifestations of woman's body are said to be "all in the mind," while the activity of her mental faculties is said to be controlled by her body. The mother is thus chosen to represent the new philosopher not only because of her creative fecundity but also because of this supposed, peculiarly female, interanimation between mind and body.

The "children" born of the convalescent-philosopher's pregnancy are his truths, not the truth but a number of truths born of his mobile perspective. In relation to traditional notions of truth as an essence to be sought behind appearance, these truths must appear to be untruths, little more than personal whimsy. Woman, as all surface and no interiority, thus comes to represent botb the alluring deceptiveness of the notion of truth as essence and the new philosopher's truths. ${ }^{50}$ So it is that at the end of the 1886 preface, the philosopher ventriloquizes:

50. I refer the reader to Derrida's discussion of "truth" and "woman" in Spurs: "There is no truth of woman but it is because that abyssal divergence of truth, this non-truth is 'truth.' Woman is a name of this non-truth of truth." Derrida, Spurs/Eperons, 51 (translation modified). Derrida both critiques and continues the Nietzschean critique of the hermeneutic model. The polemical thrust of Nietzsche's style seems to become Derrida's polemical thrust, as Derrida himself enacts a double expulsion of woman from the text. That is to say, Derrida continues to identify feminism with the castrating woman and appears to reserve for "himself" the (non)position of the "third woman." In the present context, this would seem to be yet another occupation that facilitates ventriloquism. See also his remarks in James Creech, Peggy Kamuf, and Jane Todd, "Deconstruction in America: An Interview with Jacques Derrida," Critical Exchange 17 (Winter 1985): 28-32. 
We no longer believe that truth remains truth when the veils are withdrawn; we have lived too much to believe this. Today we consider it a matter of decency not to wish to see everything naked, or to be present at everything, or to understand and "know" everything.

"Is it true that God is present everywhere?" a little girl asked her mother; "I think that's indecent"-a hint for philosophers! One should have more respect for the bashfulness with which nature has hidden behind riddles and iridescent uncertainties. Perhaps truth is a woman who has reasons for not letting us see her reasons? Perhaps her name is - to speak Greek-Baubo? (GS, 38)

The convalescent-philosopher's truth is spoken through the woman's body: Baubo, the personification of the female genitals, is the site of knowledge. It is this act of ventriloquism which Blondel seems to have in mind when he characterizes "Nietzsche's 'ontology' as feminine, or even as gynecological, for this ontology speaks of being as a woman who has no being." ${ }^{51}$ Blondel's phrase "as a woman" can, it seems to me, be read as bearing both a metaphorical and a metonymic sense: woman is metaphor of being and the gender adopted by the philosopher when he speaks of being.

Andrea Sperelli's ventriloquist moment, like Nietzsche's, is situated at the end of the narrative of convalescence. But unlike Nietzsche and Constantin Guys, Sperelli is not "toujours, spirituellement, à l'état du convalescent"; in books 3 and 4, Sperelli will return to a vita del Piacere, to that life of flirtations and seductions which had ended, temporarily, in the "mortale ferita" that had necessitated his convalescence. After the curtains close upon the scene of convalescence, he will once again feel "come un malato che abbia perduto ogni fiducia di guarire. . . . Gli pareva che di nuovo l'antica lebbra gli si dilatasse per l'anima" (Il piacere, 258) ["like a sick man who has lost all faith of getting well. . . . It seemed to him that the old leprosy once again was spreading through his soul"]. The concluding section of book 2, then, represents the culmination of Sperelli's convalescence and of his unstable

51. Blondel, 156. 
conversion to the ivory tower of art. It is here that we find the diary of a turris eburnea and androgyne, Maria Ferres.

Maria Ferres's diary has been described as the weakest point in the novel, as a discordant note in the stylistic register of Il piacere, as an anachronistic and artificial use of a technique of the eighteenthcentury novel. ${ }^{52}$ However we might choose to evaluate it, Maria's diary intrudes on the convalescent narrative and its omniscient narrator, marking a moment of rupture in the text. This moment of rupture is, I propose, due less to the diary form than to the identity of its fictional author. As I have noted, the narrative of book 2 is interspersed with sonnets and bits of poetry offered as the fruits of Sperelli's disquisitions on aesthetics. Such a combination of poetry and aesthetic theory already constitutes a disturbance of the form of the novel (if, that is, the novel is held to contain a minimum of metalanguage). Yet that disturbance appears motivated by the novel since it is, after all, Sperelli who rediscovers his poetic voice, Sperelli who elaborates a theory of aesthetics, Sperelli who projects a "poema moderno," "una lirica veramenta moderna," "un grande studio di decadenza" (Il piacere, 160) ["a modern poem," "a truly modern lyric," "a great study of decadence"]. Guided by this narrative logic, the reader-critic might reasonably expect Sperelli's works to appear as the culmination of his convalescence. The inclusion of Maria Ferres's diary thus appears unmotivated, the caprice of a young novelist. But there is something more disquieting about the diary than possible lack of skill on the part of the author. The diary clears a particular space for a voice that, as we have observed, receives special descriptive attention: "Era una voce ambigua, direi quasi bisessuale, duplice, androginica; di due tim-

52. Eurialo De Michelis's judgment is typical: "The defect becomes worse when, outside of the protagonist's representation, it is a matter of staging, in the form of an autonomous character, the 'spirituality,' 'ideality,' 'the intimate life of the heart,' all the 'things of the soul' in whose name the moral judgment is given. We allude to the attempted portrait of the exquisitely internal charms of Maria Ferres (accompanied by the usual charms, more accessible to touch). These charms are not content to be merely asserted but aspire to dictate introspective pages of a diary attributed to her, a facile expedient already typical of love novels. As introspection, these and other such pages that precede and follow the diary are among the weakest in the book." De Michelis, Tutto D'Annunzio (Milan: Feltrinelli, 1960), 80. 
bri" (Il piacere, 169) ["It was an ambiguous voice, I would almost say bisexual, double, androgynous, of two timbres"]. Maria thus has interesting potential, both as a ventriloquist and for a ventriloquist, potential Sperelli cannot resist exploiting in book 4 .

"Il timbro feminile appunto ricordava l'altra" (Il piacere, 170) ["The feminine timbre recalled the other woman"]: the feminine timbre which so reminds Andrea of Elena Muti supplies the foundation for the climactic episode of book 4 . Outside the scene of convalescence, the ex-convalescent does not attempt to project his own voice through the woman but rather the voice of another woman. Sperelli is not as unabashed as Des Esseintes, but his game is the same; rather than simply handing Maria a dialogue to memorize, he coaxes her into following his script. Maria remains unaware of the part she plays in this "staged scene":

-Quanto mi piace!

Andrea tremò. Non era quello lo stesso accento di Elena nella sua sera della dedizione? Non erano le stesse parole? Egli le guardave la bocca.

-Ripeti.

- Che cosa?

-Quello che hai detto.

-Perché?

-E una parola tanto dolce, quando tu la pronunzii... Tu non puoi intendere... Ripeti.

Ella sorrideva, inconsapevole, un po' turbata dallo sguardo singolare dell'amante; quasi timida.

-Ebbene... mi piace!

-Ed io?

-Come?

-Ed io... a te...?

Ella, perplessa, guardava l'amante che le si torceva ai piedi, convulso, nell'aspettazione della parola ch'egli voleva strapparle.

-Ed io?

53. For a discussion of this episode as a "staged scene," see Paolo Valesio, "Genealogy of a Staged Scene: Orlando furioso, V," Yale Italian Studies n.s. 1 (Spring 1980): 5-31. 
—Ah! Tu... mi piaci.

-Così, così... Ripeti. Ancòra!

Ella consentiva, inconsapevole. Egli provava uno spasimo ed una voluttà indefinibili. (344)

[ "How I love it!"

Andrea trembled. Was that not the very accent Elena had used the evening she had given herself to him? Were those not the same words? He looked at her mouth.

"Say that again."

"What?"

"What you said."

"Why?"

"It is such a sweet word, when you say it... You cannot understand... Say it again."

She smiled, unaware, a bit disturbed by her lover's odd expression, almost shy.

"Well then, I love it!"

"And me?"

"What?"

"And me? Do you love me?"

Perplexed, she looked at her lover writhing at her feet, convulsed, as he waited for the word that he wanted to draw from her.

"And me?"

"Oh! I love you."

"Yes, like that. Say it again!" She consented, unsuspecting. He experienced an indefinable voluptuous spasm.]

Maria thus unknowingly repeats the words Elena had pronounced on the occasion of her first tryst with Andrea. Elena's voice and Elena's words issuing from Maria's body send Sperelli into an erotic fury, much as Flaubert's dialogue issuing from the ventriloquist had excited Des Esseintes. His "cupo ardore" is checked only by a tragic slip of the tongue when, in the climactic episode, he calls out Elena's name in the most inappropriate of circumstances:

Nel letto, smarrita, sbigottita, innanzi al cupo ardore del forsennato, ella gridava: 
- Ma che hai? Ma che hai?

Ella voleva guardarlo negli occhi, conoscere quella follia; ed egli nascondeva il viso, perdutamente, nel seno, nel collo, ne' capelli di lei, ne' guanciali.

A un tratto, ella gli si svincolò dalle braccia, con una terribile espressione d'orrore in tutte quante le membra, più bianca de' guanciali, sfigurata più che s'ella fosse allora allora balzata di tra le braccia della Morte.

Quel nome! Quel nome! Ella aveva udito quel nome! (Il piacere, 363)

[In bed, before the dark ardor of the crazed man, bewildered and frightened, she cried, "What's wrong with you? What's the matter?" She wanted to look into his eyes, to know that madness. And he buried his face, passionately, in her breast, her neck, her hair, in the pillows.

Suddenly she disentangled herself from his arms with a terrible expression of horror in all of her limbs, whiter than the pillows, her face more distorted than if she had just then leapt from the arms of Death.

That name! That name! She had heard that name!]

This slip of the tongue is, of course, tragic for Andrea only insofar as Maria is unwilling to continue with the script. The voice of Elena issuing from the body of Maria is not merely a substitute for Elena but an exquisitely tantalizing object of desire in itself. Only Maria-with-the-voice-of-Elena can satisfy Sperelli's penchant for combining the "sacred" with the "profane." Thus, at the end of the novel Sperelli has fully exploited the "timbro feminile" of Maria's voice by transforming her into an unknowing and unwilling ventriloquist; Elena's tone becomes dominant when Maria assumes Elena's position in amor profano.

What becomes of "il timbro maschile, basso e un poco velato" (Il piacere, 169) ["the masculine timbre, low and slightly veiled"]? It is this voice, I suggest, which recounts the story of the amor sacro between Andrea and Maria. The record of her stay at Schifanoia, Maria's diary is also the account of her gradual surrender to Andrea's charms. What at first seemed a change of focus in the narrative turns out to be a sharpening of focus on Sperelli, for the count's 
opinions, tastes, and professions of love are so faithfully recorded that the diary is, for the most part, a repetition of the narrative that precedes it. Maria, the ivory tower, begins to lean when she admits to deriving pleasure from this repetition. "Tutte queste particolarità le ho dal disegnatore; provo uno strano piacere a ricordarle, a scriverle," reads one entry, and another: "Se ci fosse un mezzo, potrei riprodurre ogni modulazione della sua voce" (Il piacere, 201, 214) ["I have all of these details from the artist; I feel a strange pleasure in remembering them, in writing them down." "If there were a means, I could reproduce every modulation of his voice"]. What is added is corroboration of the emotions already expressed by Andrea; when Maria notes that "la sua voce è come l'eco dell'anima mia" (Il piacere, 269) ["his voice is like the echo of my soul"], it is because her voice is, in fact, the echo of his. Her diary is the fulfillment of Sperelli's goal:

Egli voleva possedere non il corpo ma l'anima, di quella donna; e possedere l'anima intera, con tutte le tenerezze, con tutte le gioie, con tutti i timori, con tutte le angosce, con tutti i sogni, con tutta quanta insomma la vita dell' anima; e poter dire: Io sono la vita della sua vita. (Il piacere, 180)

[He wanted to possess not the body but the soul of that woman, to possess her entire soul, with all its tenderness, all its joys, all its fears and anguish and dreams, with all the life of the soul and be able to say: - I am the life of her life.]

These are exactly the terms in which the narrator presents Maria Ferres's diary:

Maria Ferres era rimasta sempre fedele all'abitudine giovenile di notar cotidianamente in un suo Giornale intimo i pensieri, le gioie, le tristezze, i sogni, le agitazioni, le aspirazioni, i rimpianti, le speranze, tutte le vicende della sua vita interiore, componendo quasi un Itinerario dell'Anima. (Il piacere, 193)

[Maria Ferres had always remained faithful to the habit of her youth of noting daily in her personal diary the thoughts, joys, sadnesses, dreams, anxieties, aspirations, regrets, hopes, all 
the events of her inner life, composing an Itinerary of the Soul.]

The diary, then, bears witness to Maria's possession by Andrea, a possession that, as the phrase suggests, verges on the demonic. Possession is characterized as the repetition of the same words, sentiments, and desires that Andrea had used and expressed; the more Maria's voice resembles Andrea's, the more complete his possession of her. His occupation of her is total when she makes it possible for him to say, "Io sono la vita della sua vita":

-Quando, sul limite del bosco, egli colse questo fiore e me l'offerse, non lo chiamai Vita della mia vita?

Quando ripassammo pel viale delle fontane, d'innanzi a quella fontana, dove egli prima aveva parlato, non lo chiamai Vita della mia vita?

Quando tolse la ghirlanda dall'Erma e la rese a mia figlia, non mi fece intendere che la Donna inalzata ne' versi era già decaduta, e che io sola, io sola ero la sua speranza? Ed io non lo chiamai Vita della mia vita?' (Il piacere, 209)

[When, at the edge of the woods, he picked this flower and offered it to me, did I not call him Life of my life?

When we returned by the fountain path, in front of that fountain where he had first spoken, did I not call him Life of my life?

When he took the garland from the bust and gave it to my daughter, did he not give me to understand that the Woman glorified in verse had already fallen, and that I alone was his hope? And did I not call him Life of my life?]

Andrea thus succeeds in ventriloquizing; if the feminine timbre is Elena's, the masculine timbre is Andrea's. Seen against the background of the convalescences of Guys and Nietzsche, Sperelli's erotic success is a measure of his artistic failure; the masculine ideas he succeeds in transmuting into the woman's body are concupiscient rather than aesthetic. In fact, he communicates his "disease" to Maria: "Una cosa oscura e bruciante è in fondo a me, una cosa ch'è apparsa d'improvviso come un' infezione di morbo e che incomincia 
a contaminarmi il sangue e l'anima, contro ogni volontà, contro ogni rimedio: il Desiderio" (Il piacere, 215-16) ["There is something dark and burning within me, something that has appeared suddenly like an infection and has begun to contaminate my blood and soul, against all will, against all cure: Desire"]. Maria Ferres's diary thus appears to be soundly motivated precisely as testimony to Sperelli's failure as an artist, his failure to discover a new relationship between the body and thought. Sperelli's ventriloquism, like Des Esseintes's, is limited to the degradation of his muse. His convalescence ended, Sperelli writes no more but returns to "l'antica lebbra"; the unstable convert to "l'Arte . . . l'Amante fedele" now turns to Maria, "l'Amante Ideale."

Sperelli's artistic failure could seem a parody of Guys's and Nietzsche's "successes," a reliteralization of the man's occupation of the woman, only if Il piacere is considered apart from D'Annunzio's other novels. Sickness and convalescence are major preoccupations in his prose works, both before and after Il piacere, and in the 1921 Notturno convalescence appears once again as the scene of artistic creation. The narrator of Notturno succeeds where Sperelli had failed. Here sickness and convalescence truly become an alibi for a new prose style, a style that D'Annunzian criticism prefers to that of the earlier novels precisely because of its "modernity." the convalescent of Notturno is successful in another sense as well, for he achieves this stylistic modernity by adopting a "feminine" mode of writing.

D'Annunzio assumes the guise of D'Annunzio in Notturno; the narrator lies in the dark, convalescing from a wound to the eye like that D'Annunzio had actually received in World War I. This temporary blindness ("Ho gli occhi bendati") represents a material obstacle to the writer's practical functioning, and a new mode of writing must be devised for him:

M'era vietato il discorrere e in ispecie il discorrere scolpito;

54. One of the commonplaces of D'Annunzian criticism, this preference is so widespread as to deserve a separate article in which to list all of its proponents. Ermanno Circeo's intelligent overview of D'Annunzian criticism describes the major camps: Il D'Annunzio "notturno" e la critica dannunziana di un settantennio (Pescara: Trimestre, 1975). 
né m'era possibile vincere l'antica ripugnanza alla dittatura e il pudore segreto dell'arte che non vuole intermediarii o testimonii fra la materia e colui che la tratta. L'esperienza mi dissuadeva dal tentare a occhi chiusi la pagina. La difficoltà non è nella prima riga ma nella seconda e nelle seguenti. Allora mi venne nella memoria la maniera delle Sibille che scrivevano la sentenza breve su le foglie disperse al vento dal fato. 55

[All forms of discourse, and in particular sculpted discourse, were forbidden me. Nor could I overcome my old revulsion against dictation and the secret modesty of art that wants no intermediaries or witnesses between the matter and him who forms it. Experience dissuaded me from attempting the page with eyes closed. The difficulty lies not in the first line, but in the second and all those that follow. Then I remembered the technique of the Sibyls, who wrote their short sentences on sheets of paper dispersed to the winds by Fate.]

Strips of paper are cut for the convalescent in order that he might adopt the sibylline mode of writing, which is the technical motivation of the prose style, impressionistic and lapidary, of Notturno. The ventriloquism of Notturno is less corporeal than that of Lepeintre de la vie moderne, The Gay Science, or Il piacere, but not thereby less complete. The image of the blindfolded narrator becomes, in Il compagno dagli occhi senza cigli, the image of his muse: "La malattia e la morte son le due muse bendate che ci conducono in silenzio a scoprire la spiritualità delle forme" ["Sickness and death are the two blindfolded muses who lead us in silence to discover the spirituality of forms"]. ${ }^{56}$ If Sperelli degraded his muse and mislaid his poetic inspiration, the convalescent-narrator of Notturno is at once inspired writer and his own muse. Far from parodying and

55. Gabriele D'Annunzio, Notturno, in Prose di ricerca di lotta, di comando, di conquista, di tormento, d'indovinamento, di rinnovamento, di celebrazione, di rivendicazione, di liberazione, di favole, di giochi, di baleni, Tutte le opere di Gabriele D'Annun$z i o$, ed. Egidio Bianchetti (Milan: Mondadori, 1954), 1:172.

56. D'Annunzio, Il compagno dagli occhi senza cigli, in Prose di ricerca (Milan: Mondadori, 1956), 2:614. 
then abandoning the decadent ideologeme of convalescence, D'Annunzio brings it to perfection in Notturno. The twist given the scene of convalescence in Il piacere is thus a comment upon Sperelli's exaggerated opinion of his own talents, rather than a lack of talent on the part of D'Annunzio; it is a deviation from the Baudelairean rhetoric of convalescence which relies upon that rhetoric for its interpretation. 